\title{
Results of Research to Evaluate Solid Plutonium Nitrate as a Safe Shipping Form
}

\author{
G. H. Bryan \\ J. K. Thompson \\ H. H. Van Tuyl \\ C. L. Brown \\ J. L. Ryan
}

November 1976

Prepared for the Energy Research and Development Administration under Contract E(45-1)-1830 
NOTICE

This report was prepared as an account of work sponsored by the United States Government. Neirher the United States nor the Energy Research and Development Administration, nor any of their employees, nor any of their contractors, subcontractors, or their employees, makes any warranty, express or implied, or assumes any legal liability or responsibility for the accuracy, completeness or usefulness of any imformation, apparatus, product or process disclosed, or represents that its use would not infringe privately owned rights.

PACIFIC NORTHWEST LABORATORY

operated by

BATTELLE

for the

ENERGY RESEARCH AND DEVELOPMENT ADMINISTRATION

Under Contract $E(45-1)-1830$

Printed in the United States of America Available from

National Technical Information Service

U.S. Department of Commerce

5285 Port Royal Road

Springfield, Virginia 22151

Price: Printed Copy S4.SO; Microfiche \$2.25 


\title{
33679000625717
}

\section{RESULTS OF RESEARCH TO EVALUATE SOLID}

PLUTONIUM NITRATE AS A SAFE SHIPPING FORM

\author{
GH Bryan \\ JK Thompson \\ HH Van Tuyl \\ $\mathrm{CL}$ Brown \\ IL Ryan
}

November 1976

BATTELLE

PACIFIC NORTHWEST LABORATORIES

Richland, Washington 99352 


\section{TABLE OF CONTENTS}

LIST OF TABLES. .......................

LIST OF FIGURES ........................ iv

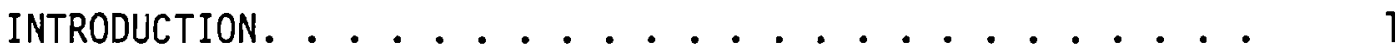

SUMMARY AND CONCLUSIONS ............... 3

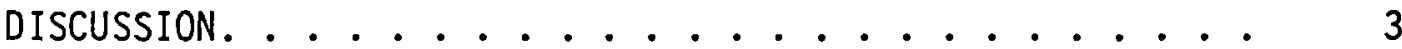

BACKGROUND. ..................... 3

EXPERIMENTAL. ..................... 5

Plutonium Composition ............... 5

Plutonium Compound. ............. 5

Experimental Procedure............ 6

Results ............... 10

A. Radiolytic Gas Generation. . . . . . . . . 10

B. Thermal Stability............ 19

C. X-ray Analysis .............. 2 22

D. Effect of Radiation on Solubility. . . . . . 22

E. Pilot-Plant Work ............ 25

BASIS FOR FUTURE SHIPPING PACKAGE DESIGN. . . . . . 26

Fuel Composition. . . . . . . . . . 27

Therma1 Decay Energy. . . . . . . . . 27

Radiolytic Gas Evolution. . . . . . . . . 28

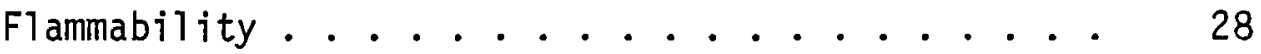

Pressurization ................ . . 29

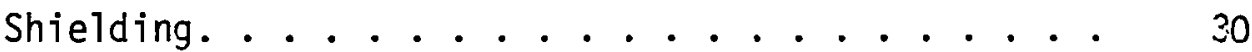

Criticality.............. 31

REFERENCES. ............... 34 APPENDIX 1 


\section{LIST OF TABLES}

$184.8 \%{ }^{238} \mathrm{Pu}$ Isotopic Composition. . . . . . . . 5

$217.4 \%{ }^{238} \mathrm{Pu}$ Isotopic Composition. ........ 5

3 Isotopic Composition of Plutonium Nitrate Feed. . . . 9

4 Plutonium Nitrate Feed Impurities......... 9

5. Composition of Radiolytic Gases in Mole Percent

Evolved From $\mathrm{Pu}\left(\mathrm{NO}_{3}\right)_{4} \cdot \mathrm{XH}_{2} \mathrm{O},\left(\mathrm{NH}_{4}\right)_{2} \mathrm{Pu}\left(\mathrm{NO}_{3}\right)_{6}$, and

$\mathrm{K}_{2} \mathrm{Pu}\left(\mathrm{NO}_{3}\right)_{6}$ as a Function of Accumulated Alpha Dose. . 16

6. Estimated Composition of Recycle Plutonium. . . . . 27

7 Estimated Decay Heat For Various ${ }^{241} \mathrm{Pu} /{ }^{241}$ Am Ratios (238Pu Held Constant).......... 27

8 Thermal Decay Heat Constants For ${ }^{241}$ Am and Isotopes of Plutonium. . . . . . . . . . . 28

9 Estimated Dose Rates For Recycle Plutonium. . . . . 30

$10 \mathrm{Pu}\left(\mathrm{NO}_{3}\right)_{4} \cdot 5 \mathrm{H}_{2} \mathrm{O}$ - Spherical Geometry. . . . . . . 31

$11 \mathrm{PuO}_{2}$ - Spherical Geometry . . . . . . . . 33

12 Cylindrical Geometry - Critical Radius (cm) .... . 33 


\section{LIST OF FIGURES}

1 Radiolytic Gas Measurement Apparatus . . . . . . . 7

2 Evaporation Vessel ................ 11

3 Equipment Schematic. . . . . . . . . . . 12

$4 G_{T}$ Value Versus Accumulated Dose........... 13

5 Total Moles of Gas Produced As a Function of Accumulated Dose . . . . . . . . . . . . 15

6 Thermogravimetric Curve For Plutonium Nitrate. . . . . 20

7 Thermogravimetric Curve for Potassium Hexanitratoplutonate.................... 21

8 Thermogravimetric Curve for Ammonium Hexanitratoplutonate................... 22

9 X-ray Powder Diffraction Patterns. . . . . . . . 24

10 Plutonium Density as a Function of $\mathrm{H} / \mathrm{Pu}$ Atom Ratio . . 32 
RESULTS OF RESEARCH TO EVALUATE SOLID

PLUTONILIM NITRATE AS A SAFE SHIPPING FORM

\author{
GH Bryan \\ JK Thompson \\ HH Van Tuy 1 \\ CL Brown \\ JL Ryan \\ INTRODUCTION
}

Plutonium used in commercial experimental $\mathrm{PuO}_{2}-\mathrm{UO}_{2}$ fuels is shipped to fuel fabricators in two forms: $\mathrm{Pu}\left(\mathrm{NO}_{3}\right)_{4}$ solution and $\mathrm{PuO}_{2}$ powder. In 1973, the USAEC amended its regulation 10 CFR Part 71 to require that after June 17, 1978 all plutonium in quantities greater than 20 curies be packaged for shipment as a solid (see Appendix 1). After that date the shipment of plutonium nitrate solution will be prohibited.

Depending on the outcome of nuclear reactor performance tests with the experimental mixed oxide fuels, fuel fabricators will decide on a best starting material for the fuel $-\mathrm{Pu}\left(\mathrm{NO}_{3}\right)_{4}$ solution or dry $\mathrm{PuO}_{2}$ powder. At first glance, plutonium oxide would seem to be the first choice. It is a stable, fairly easily made powder that would seem to "fill the bill" as an almost ideal shipping form. The oxide, however, is an extremely difficult compound to dissolve in nitric acid alone and the use of hydrofluoric acid is usually necessary. Hydrofluoric acid reacts with stainless steel, thus presenting problems with use of ordinary materials for glove box construction, piping and storage tanks. Purification of the plutonium, which may be necessary after long storage times, is also difficult until the fluoride ion is either complexed or removed. This requires the use of more chemicals which can oniy add to waste disposal problems. The presence of the fluoride also tends to increase the neutron flux, making shielding more difficult and expensive.

With the above listed difficulties in mind for the use of $\mathrm{PuO}_{2}$, a program was funded by the Division of Waste Management and Transportation 
to define new chemical forms for the shipment of plutonium as a solid. The criteria for the type of material needed were as follows:

1. Solid

2. Readily soluble in $\mathrm{HNO}_{3}$

3. Inexpensive to prepare

4. Minimum amount of explosive or flammable gas produced by radiolysis

5. Reasonable storage life without conversion to oxide or some other insoluble form

This material is intended to provide a more convenient form than the oxide for fuel cycle purposes. It would allow the fuel fabrication segment of the fuel cycle to store a solid that could be easily purified before conversion to the oxide without use of specially designed facilities that are able to withstand the use of hydrofluoric acid.

The three compounds chosen for evaluation were $\mathrm{Pu}\left(\mathrm{NO}_{3}\right)_{4} \cdot \mathrm{XH}_{2} \mathrm{O}, \mathrm{K}_{2} \mathrm{Pu}\left(\mathrm{NO}_{3}\right)_{6}$ and $\left(\mathrm{NH}_{4}\right)_{2} \mathrm{Pu}\left(\mathrm{NO}_{3}\right)_{6}$. The nitrates were selected since they would not add an extraneous anion to the process streams. The halides were ruled out since they would not be compatible with stainless steel, and organics were not felt to be sufficiently stable for use.

A systematic study of the radiolytic and thermal stability, solubility, and ease of preparation of each of the three nitrate compounds selected was then accomplished. These results allowed each compound to be evaluated as a potential solid shipping form as a guide to shipping package requirements.

This report presents the results of the chemical development on a laboratory scale. Pilot plant development work on a one-kg scale was begun by Atlantic Richfield-Hanford Company but not completed in FY-1975. (a) If warranted, a later phase will evaluate pilot facility operations and packaging development for shipment of solid plutonium nitrate.

a. Work performed by R. E. Felt and P. C. Ely, ARHCO. A formal report summarizing the results of this work is to be published at a later date. 
SUMMARY AND CONCLUSIONS

The results of the research described in this report indicate that the compound $\mathrm{Pu}\left(\mathrm{NO}_{3}\right)_{4} \cdot \mathrm{XH}_{2} \mathrm{O}$ is a viable material for consideration as a solid shipping form. It meets the criteria, as outlined in the introduction, set. forth to define a suitable solid form of plutonium.

Several plutonium compounds were considered for study as a shipping form before selecting $\mathrm{Pu}\left(\mathrm{NO}_{3}\right)_{4} \cdot \mathrm{XH}_{2} \mathrm{O}$ as having the most desirable characteristics. It is reasonably easy to prepare on a kilogram scale with relatively simple equipment using vacuum evaporation techniques. Plutonium nitrate does begin to thermally decompose at about $100^{\circ} \mathrm{C}$; however, proper equipment design and instrumentation can overcome this problem.

Although $\mathrm{Pu}\left(\mathrm{NO}_{3}\right)_{4} \cdot \mathrm{XH}_{2} \mathrm{O}$ does produce some radiolytic gases, such as oxygen and nitrogen, an explosive mixture is not produced as only minor amounts of hydrogen are formed except during extended storage. Excessive pressurization in the shipping mode should not be a problem if the transport container is not closed for protracted periods of time. However, some form of thermal insulation would be required to prevent decomposition of the compound and to preclude over-pressurization during a fire.

Plutonium nitrate has been found to be completely soluble in nitric acid even after storage for extended periods of time. After the equivalent of 25 years of storage time of first-cycle reactor-grade plutonium from a radiation damage standpoint, $\mathrm{Pu}\left(\mathrm{NO}_{3}\right)_{4} \cdot \mathrm{XH}_{2} \mathrm{O}$ prepared from $85 \%{ }^{238} \mathrm{Pu}$ was found to be completely soluble in $4 \mathrm{MNNO}_{3}$. Plutonium nitrate was also found to be soluble in water, but it rapidly converted to plutonium polymer.

A possible shipping form other than plutonium oxide has been described in this work. More research is required before the final acceptance of $\mathrm{Pu}\left(\mathrm{NO}_{3}\right)_{4} \cdot \mathrm{XH}_{2} \mathrm{O}$ as an a7ternate form; however, it does appear to meet established criteria.

\section{DISCUSSION}

BACKGROIJND

At the present time there is considerable debate concerning the relative risk of transporting plutonium in nitrate solution versus the oxide form. Some 
of the characteristics of plutonium nitrate solution which might make it less desirable to ship are as follows:

- Nitrate is a liquid, whereas current trends are for shipments of radioactive material in the solid form. It is felt that the potential for release in an uncontrolled manner may be greater for liquids than for solids. In addition, liquid solutions have the potential for producing steam pressurization within the package if sufficient heat is available.

- Plutonium nitrate solution has the potential hazard of pressurization of the container due to the radiolysis of water. The hydrogen and oxygen gas mixture which is evolved eventually could result in significant pressurization or explosion of the containment vesse1.

It is generally recognized that the most vulnerable part of the nuclear fuel cycle for harm to the public from radioactive material is during the transportation mode. Thus, there is considerable emphasis at this time on increasing the safety of this portion of the fuel cycle. If nitrate shipments are to continue, it must be demonstrated that the potential hazards referred to above can be reduced or eliminated to a reasonable level with respect to the hazard associated with transportation of oxide.

If it can be shown that the nitrate solid form and the associated shipping package represent significant improvements in safety of plutonium shipments, this would have a significant impact on public acceptance of the nuclear fuel cycle.

This program will investigate the conversion of plutonium nitrate solutions to solid forms in a variety of ways and measurement of the properties of the forms thus produced. Candidate product forms which are found to be suitable from radiolytic considerations will also be characterized for thermal stability, thermal conductivity, heat capacity, and other parameters which are of interest in both shipping cask design and in transportation safety analysis. 
EXPERIMENTAL

Plutonium Composition

The $84.8 \%{ }^{238} \mathrm{Pu}$ used in this work was prepared by neutron irradiation of ${ }^{237} \mathrm{~Np}$. The $17.4 \%{ }^{238} \mathrm{Pu}$ was prepared by mixing appropriate amounts of nitric acid solutions of the $84.8 \%{ }^{238} \mathrm{Pu}$ and $91.3 \%{ }^{239} \mathrm{Pu}$. The results of mass spectrometric isotopic analysis of the final product in each case are shown in Tables 1 and 2. A11 other chemicals were reagent grade and were used without further purification.

Plutonium Compounds

The simple plutonium nitrate salt $\left(\mathrm{Pu}\left(\mathrm{NO}_{3}\right)_{4} \cdot \mathrm{XH}_{2} \mathrm{O}\right)$ was prepared from an $8 \mathrm{M}$ nitric acid solution of plutonium nitrate by vacuum evaporation at 1 torr and ambient temperature. Samples prepared from $17.4 \%{ }^{238} \mathrm{Pu}$ and $91.3 \%{ }^{239} \mathrm{Pu}$ required from $3-5$ days to prepare a solid material. Less than 24 hours was required with the $84.8 \%{ }^{238} \mathrm{Pu}$ due to self heating.

TABLE 1. $84.8 \%{ }^{238} \mathrm{Pu}$ Isotopic Composition

$\begin{array}{lc}\text { Pu-238 } & 84: 8 \pm 0.06 w t \% \\ \text { Pu-239 } & 11.19 \pm 0.06 w t \% \\ \text { Pu-240 } & 3.22 \pm 0.02 w t \% \\ \text { Pu-241 } & 0.665 \pm 0.007 w t \% \\ \text { Pu-242 } & 0.122 \pm 0.003 w t \%\end{array}$

TABLE 2. $17.4 \%{ }^{238} \mathrm{Pu}$ Isotopic Composition

$\begin{array}{cc}\text { Pu-238 } & 17.4 \pm 0.1 w t \% \\ \text { Pu-239 } & 74.9 \pm 0.1 w t \% \\ \text { Pu-240 } & 0.635 \pm 0.005 w t \% \\ \text { Pu-241 } & 0.635 \pm 0.005 w t \% \\ \text { Pu-242 } & 0.079 \pm 0.002 w t \%\end{array}$

The starting plutonium concentration in all cases was about $230 \mathrm{~g} / \mathrm{l}$. 
The potassium and ammonium hexanitrato plutonate salts were prepared by the addition of a $10 \%$ stoichiometric excess of potassium or ammonium nitrate to plutonium nitrate in $8 \mathrm{M}$ nitric acid, followed by vacuum evaporation at ambient temperature. Once again, the $84.8 \%{ }^{238} \mathrm{Pu}$ compounds required less than 24 hours to prepare while those samples having lesser amounts of ${ }^{238} \mathrm{Pu}$ required 3-5 days of evaporation before dryness was obtained.

\section{Experimental Procedure}

During the course of evaporation the simple plutonium nitrate $\left(\mathrm{Pu}\left(\mathrm{NO}_{3}\right)_{4}\right.$. $\mathrm{XH}_{2} \mathrm{O}$ ) became extremely viscous before becoming a solid, indicating a very high solubility. The potassium and ammonium salts are less soluble and crystallized during the course of evaporation. The uranium salt $\mathrm{KUO}_{2}\left(\mathrm{NO}_{3}\right)_{3}$ was prepared for $x$-ray powder pattern comparison analysis by the mixing of stoichiometric amounts of $\mathrm{KNO}_{3}$ and $\mathrm{UO}_{2}\left(\mathrm{NO}_{3}\right)_{2}$ in nitric acid followed by filtering, washing, and drying.

The rate of radiolytic gas generation was measured using the apparatus shown in Figure 1. A weighed sample of the compound to be tested was placed in the sample container and held in place with a glass wool plug. The sample container was then placed in a stainless steel outer sample container with a cap containing a stainless steel frit to allow the passage of gases. The stainless steel sample container was placed in the gas measurement apparatus and the system purged with helium gas for 30 minutes with pressure pulsing to insure removal of all other gases. This arrangement was found to contain the plutonium compound under study quite well and allowed measurements to be taken in an open hood without contamination of the apparatus.

A $10 \mathrm{~mm}$ layer of silicone oil was placed on top of the mercury on each side of the manometer prior to use to retard reaction with any corrosive gases produced during the course of the experiment. All manometer readings were obtained by use of a cathetometer.

Gas samples were taken by evacuating the sample collector and the area between the collector and the measurement apparatus with the gas then being drawn into the collector from the apparatus. Samples were analyzed on a 


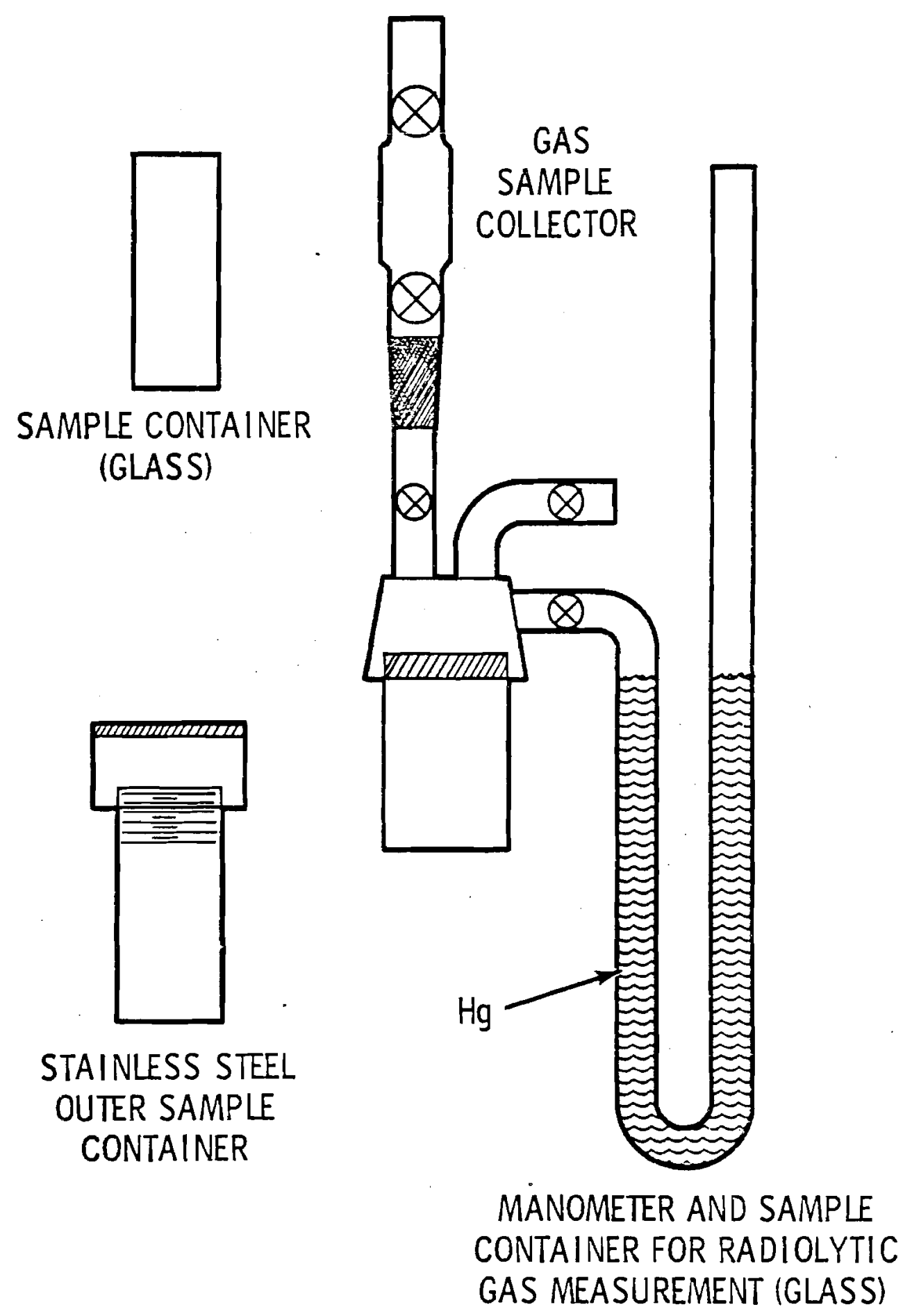

FIGURE 1. RADIOLYTIC GAS MEASUREMENT APPARATUS 
Consolidated Electrodynamics Corporation 21-103 mass spectrometer to determent the composition of gases that had been produced.

The amount of gas generated by the solid per $100 \mathrm{ev}$ ( $G_{T}$ vãiue) was calculated using the ideal gas $1 \mathrm{aw}$, and the dose rate of the material used, as determined by the following equation:

$$
\begin{aligned}
\text { Dose Rate }= & \text { (Sp. activity } \left.{ }^{239} \mathrm{Pu}\right) \mathrm{E}_{\alpha}[\% \mathrm{Pu}-239+3.7(\% \mathrm{Pu}-240)+302(\% \mathrm{Pu}-238) \\
& \left.+60(\% \mathrm{Pu}-241)\left(1-\mathrm{e}^{-0.049 \mathrm{Y}}\right)\right] \\
& E_{\alpha}=\text { alpha energy of }{ }^{239} \mathrm{Pu} \text { in electron volts } \\
& Y=\text { time in years since chemical separation of Am from Pu. }
\end{aligned}
$$

The ${ }^{238} \mathrm{Pu}$ contributes, by far, the largest amount of energy in the case of the $84.8 \%{ }^{238} \mathrm{Pu}$ material allowing the energy contributions of the other isotopes to be disregarded.

Thermogravimetric analyses were obtained using an Ainsworth Semimicro Recording Balance. A1l analyses were made in an air atmosphere to duplicate actual conditions to which the compound might be subjected in the shipping mode. This procedure al so converted each compound to $\mathrm{PuO}_{2}$, and the final $\mathrm{PuO}_{2}$ weight was used as the basis for calculation of the original molecular weight of the material in question. A heating rate of $2^{\circ} \mathrm{C} / \mathrm{min}$ was used in all cases.

X-ray analyses were performed on a General Electric SRD-5 x-ray diffractometer. Analyses were performed on samples of all compounds, as well as any intermediates found during thermogravimetric analysis. Patterns were obtained only for those materials which were prepared from $91.3 \%{ }^{239} \mathrm{Pu}$. A11 others were found to be amorphorous.

The pilot-plant scale work to produce kilogram quantities of $\mathrm{Pu}\left(\mathrm{NO}_{3}\right)_{4}$. $\mathrm{XH}_{2} \mathrm{O}$ was accomplished using 4 liters of plutonium nitrate solution that was initially $5 \mathrm{M}$ in nitric acid and contained 920 grams of plutonium. The isotopic composition and impurities are shown in Tables 3 and 4. 
TABLE 3. Isotopic Composition of Plutonium Nitrate Feed

\begin{tabular}{cc} 
Isotope & Percent Abundance \\
\cline { 2 - 2 } $238 \mathrm{Pu}$ & 0.062 \\
$239 \mathrm{Pu}$ & 89.667 \\
$240 \mathrm{Pu}$ & 8.907 \\
$241 \mathrm{Pu}$ & 1.159 \\
$242 \mathrm{Pu}$ & 0.205
\end{tabular}

TABLE 4. Plutonium Nitrate Feed Impurities

\begin{tabular}{|c|c|}
\hline \\
\hline & \\
\hline \multicolumn{2}{|c|}{$\mathrm{Ag}$} \\
\hline As & \\
\hline$B$ & \\
\hline $\mathrm{Ba}$ & \\
\hline $\mathrm{Be}$ & \\
\hline$B i$ & \\
\hline $\mathrm{Ca}$ & \\
\hline $\mathrm{Cd}$ & \\
\hline Co & \\
\hline $\mathrm{Cr}$ & \\
\hline $\mathrm{Cu}$ & \\
\hline $\mathrm{Fe}$ & \\
\hline $\mathrm{Ga}$ & \\
\hline$K$ & \\
\hline Li & \\
\hline
\end{tabular}

$\frac{\text { Element }}{M g} \quad \frac{P P M}{100}$

$\mathrm{Mn} \quad 25$

Mo $<10$

$\mathrm{Na} \quad 400$

$\mathrm{Nb} \quad<8$

$\mathrm{Ni} \quad<50$

$P \quad 250$

$\mathrm{Pb}<<10$

$\mathrm{Si} \quad<40$

Sn $<15$

$\mathrm{Ta}<40$

$\mathrm{Ti} \quad 400$

$V \quad<50$

$W \quad<10$

$\mathrm{Zn} \quad<20$

$\mathrm{Zr} \quad 200$ 
The evaporation vessel in which all large-scale operations were performed is shown in Figure 2. The Equipment Schematic for the pilot-plant scale work was as shown in Figure 3.

\section{Results}

\section{A. Radiolytic Gas Generation}

The $G_{T}$ values (molecules per $100 \mathrm{ev}$ ) have been calculated as a function of accumulated radiation dose for each of the three compounds under consideration $\left[\mathrm{Pu}\left(\mathrm{NO}_{3}\right)_{4} \cdot \mathrm{XH}_{2} \mathrm{O}, \mathrm{K} 2 \mathrm{Pu}\left(\mathrm{NO}_{3}\right)_{6}\right.$, and $\left.\left(\mathrm{NH}_{4}\right)_{2} \mathrm{Pu}\left(\mathrm{NO}_{3}\right)_{6}\right]$, as shown in Figure 4. The high $\mathrm{G}_{T}$ values found in the case of $\left(\mathrm{NH}_{4}\right)_{2} \mathrm{Pu}\left(\mathrm{NO}_{3}\right)_{6}$ were not completely unexpected as the $\mathrm{NH}_{4}^{+}$ion is rather sensitive to radiation damage producing gaseous products. (1) The $\mathrm{G}_{\mathrm{T}}$ values of $\mathrm{Pu}\left(\mathrm{NO}_{3}\right)_{4} \cdot \mathrm{XH}_{2} \mathrm{O}$ and $\mathrm{K}_{2} \mathrm{Pu}\left(\mathrm{NO}_{3}\right)_{6}$ were found to be similar (each decreasing with accumulated dose and approaching a value of about 0.025 above about $10^{18} \mathrm{Mev} / \mathrm{g} \mathrm{Pu}$ ).

Each of the compounds was prepared with $84.8 \%{ }^{238} \mathrm{Pu}$ to accelerate the acquisition of data. The simple plutonium nitrate $\left(\mathrm{Pu}\left(\mathrm{NO}_{3}\right)_{4} \cdot \mathrm{XH}_{2} \mathrm{O}\right)$ was al so prepared using $17.4 \%{ }^{238}$ Pu as TGA results indicated the $84.8 \%$ material did not have the proper molecular weight and may have degraded to some intermediate (see TGA section for further explanation). Therefore, the numbers used for Figure 4 were found using the $17.4 \%{ }^{238} \mathrm{Pu}$ material which also more closely simulated actual reactor grade ${ }^{238} \mathrm{Pu}$ content.

Given the $G_{T}$ values, the rate of radiolytic gas generation with a specified amount of $\mathrm{Pu}\left(\mathrm{NO}_{3}\right)_{4} \cdot \mathrm{XH}_{2} \mathrm{O}$ is $\mathrm{g}_{\mathrm{Pu}}\left(\frac{\mathrm{sp} \text {. activity }}{6.08 \times 10^{23}}\right) E_{\alpha} G_{T} / 100=1.67 \times 10^{-5}$ $g_{P u} G_{T} \quad[(\% P u-239)+3.7(\% P u-240)+302(\% P u-238)+60(\% P u-241)$ $\left.\left.1-e^{-0.049 Y}\right)\right]$ moles gas per day and $G_{T}=G_{\left(\mathrm{H}_{2}\right)}+G_{\left(\mathrm{O}_{2}\right)}+G_{\left(\mathrm{N}_{2}\right)}+\ldots$

The rate of pressurization in a given container will be:

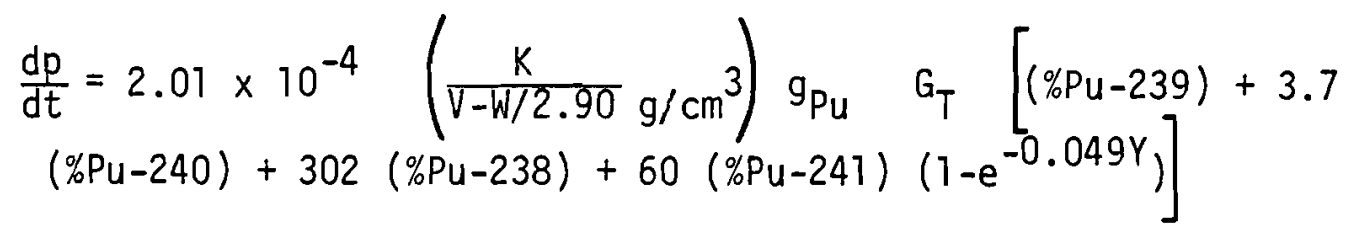




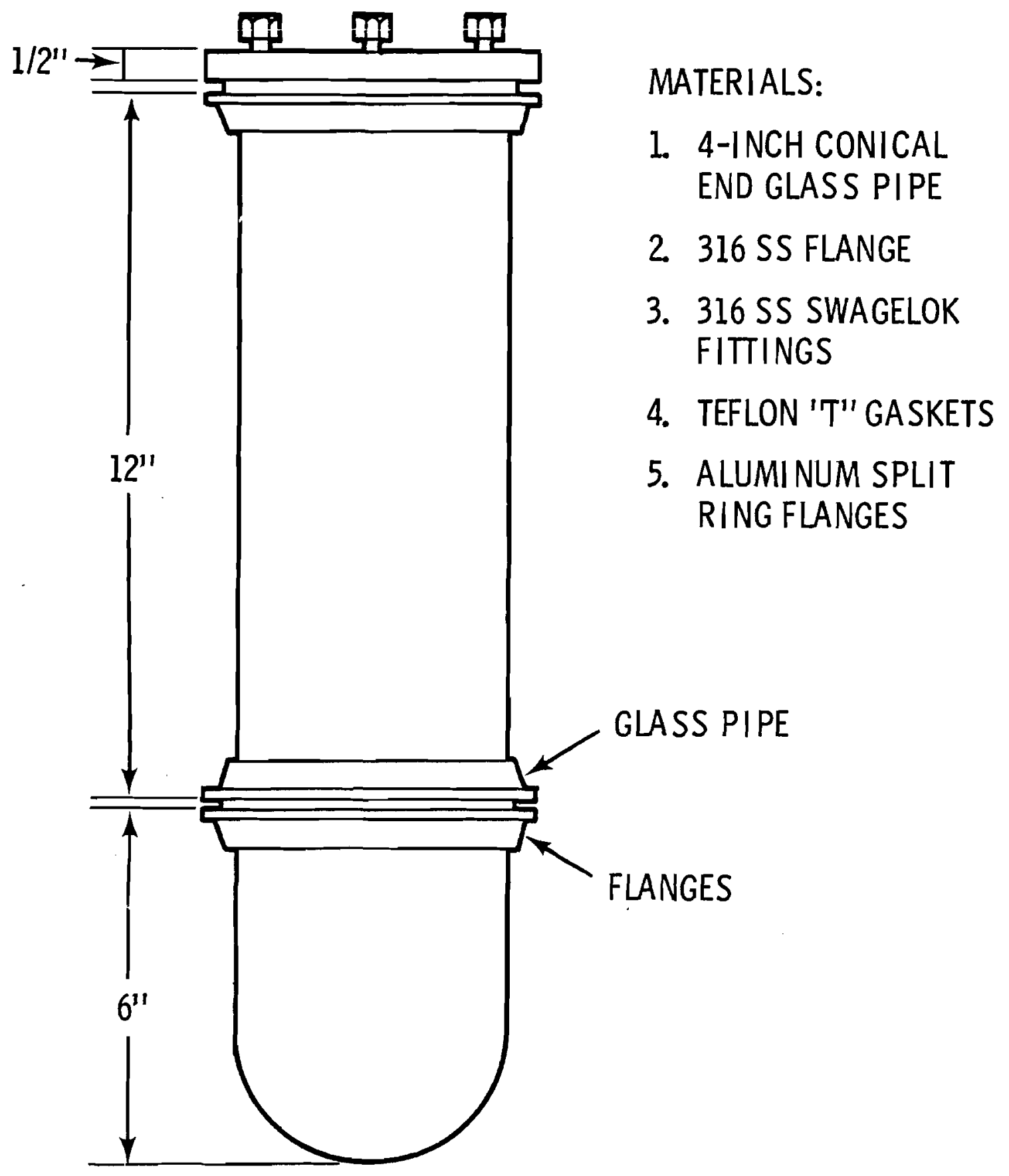

FIGURE 2. EVAPORATION VESSEL 


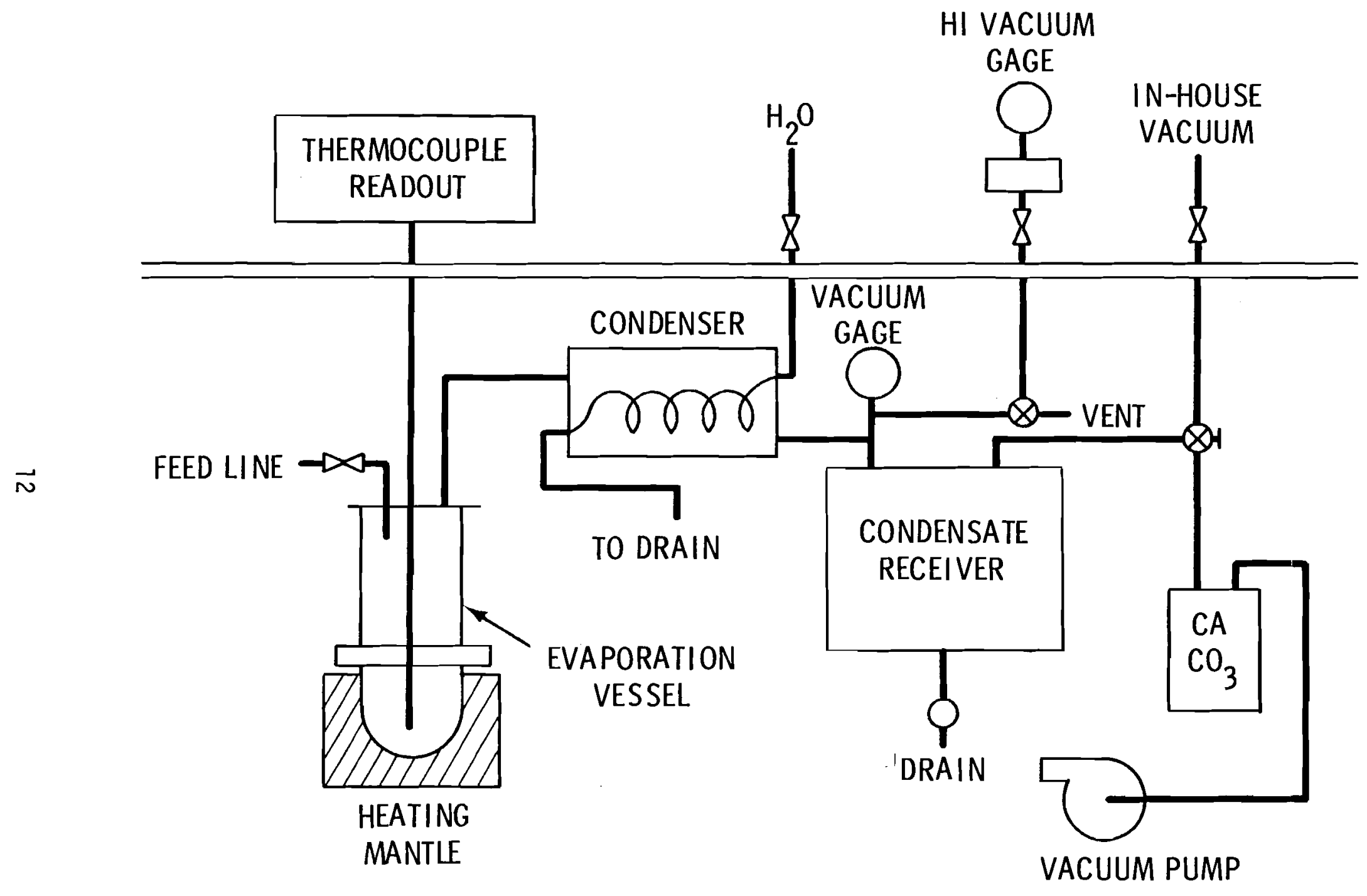

FIGURE 3. EQUIPMENT SCHEMATIC 


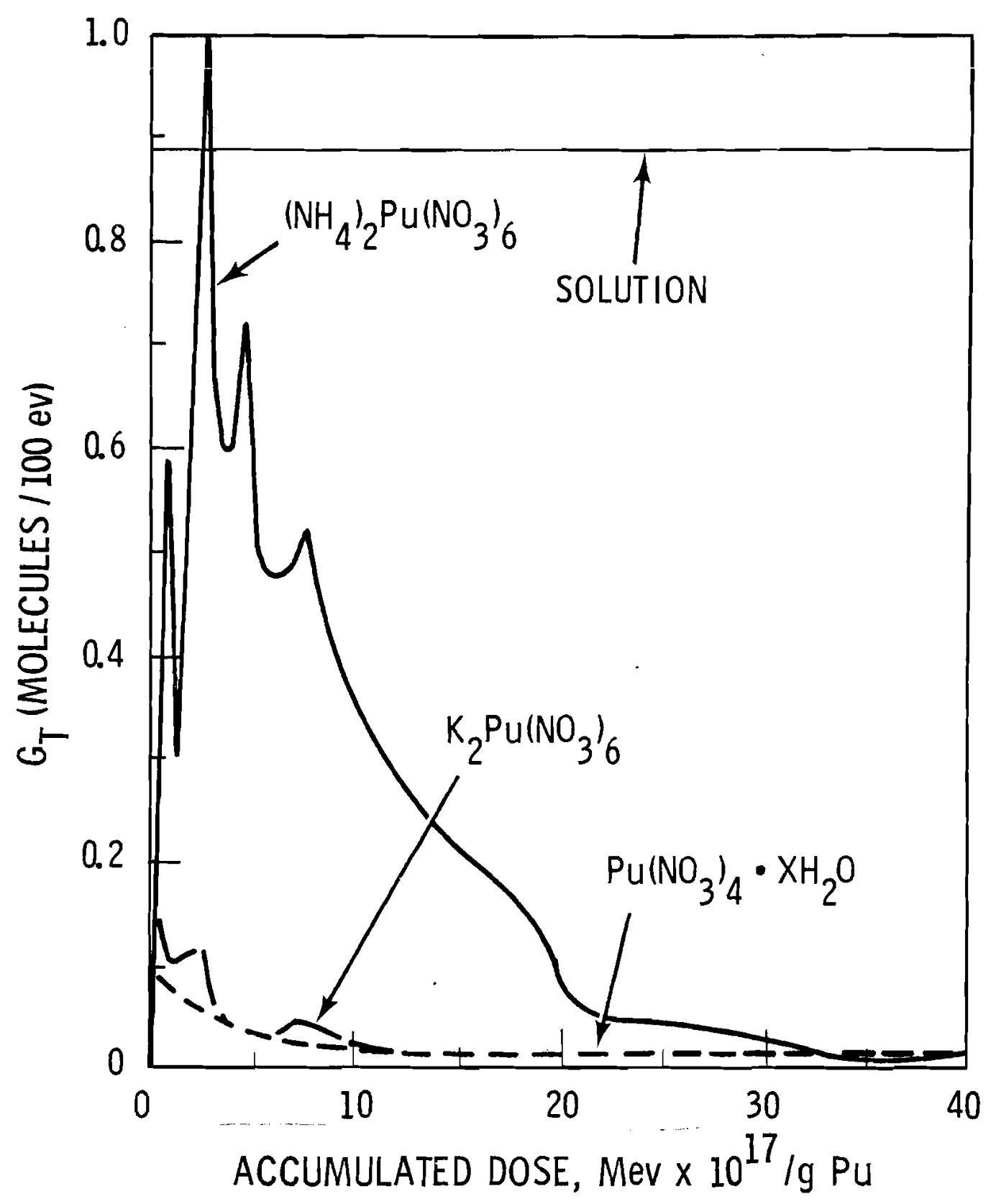

FIGURE 4. G VALUE VS ACCUMULATED DOSE 
where $K=$ degrees Kelvin

$t=$ time in days

$\mathrm{V}=$ container volume in $\mathrm{ml}$

$W=$ weight of $\mathrm{Pu}\left(\mathrm{NO}_{3}\right)_{4} \cdot \mathrm{XH}_{2} \mathrm{O}$ of density $2.90 \mathrm{~g} / \mathrm{cm}^{3}$ (ref. 6)

$Y=$ time in years since chemical separation of Am from $\mathrm{Pu}$

$E_{\alpha}=$ alpha energy in electron volts

$g_{P u}=$ grams plutonium

$p=$ pressure in psi.

Figure 5 gives the total accumulated gas production as a function of total accumulated radiation dose for $\mathrm{Pu}\left(\mathrm{NO}_{3}\right)_{4} \cdot \mathrm{XH}_{2} \mathrm{O}$. In this plot, the origin represents the point at which the $\mathrm{Pu}\left(\mathrm{NO}_{3}\right)_{4} \cdot \mathrm{XH}_{2} \mathrm{O}$ was prepared. By determining from this plot the difference between the accumulated gas production at the time (and accumulated dose) a container is sealed and some later time (and accumulated dose), the tota 1 gas production in the container is obtained. From this and the container void volume the pressure is easily calculated.

Hydrogen is not a major constituent (see Table 5) in any of the three cases studied and should not present an explosive hazard. Upon long term storage the relative amount of radiolytic hydrogen does increase in the case of $\mathrm{Pu}\left(\mathrm{NO}_{3}\right)_{4} \cdot \mathrm{XH}_{2} \mathrm{O}$, but when viewed from the standpoint of total gas produced by the solid, it remains at a low level.

The mechanism by which the gases (see Table 5) are formed during the radiolysis of each compound is not fully understood. Products usually associated with the alpha-radiolysis of nitrate solutions have been studied $(2,3)$ to some extent, and have been found to usually contain nitrites, hydrogen peroxide, hydrogen, and oxygen. Several papers have been published on the decomposition of inorganic nitrates; $(4,5,6,7,8)$ however, they deal with salts that were irradiated with gamma or x-rays and so do not necessarily correspond to experimental results found during this research.

The studies that have been made on the radiation-induced decomposition of inorganic nitrates show a very complex nature. Different nitrates show varying degrees of stability when exposed to ionizing radiation leading to numerous explanations for the different yields (G-values) that are observed. 


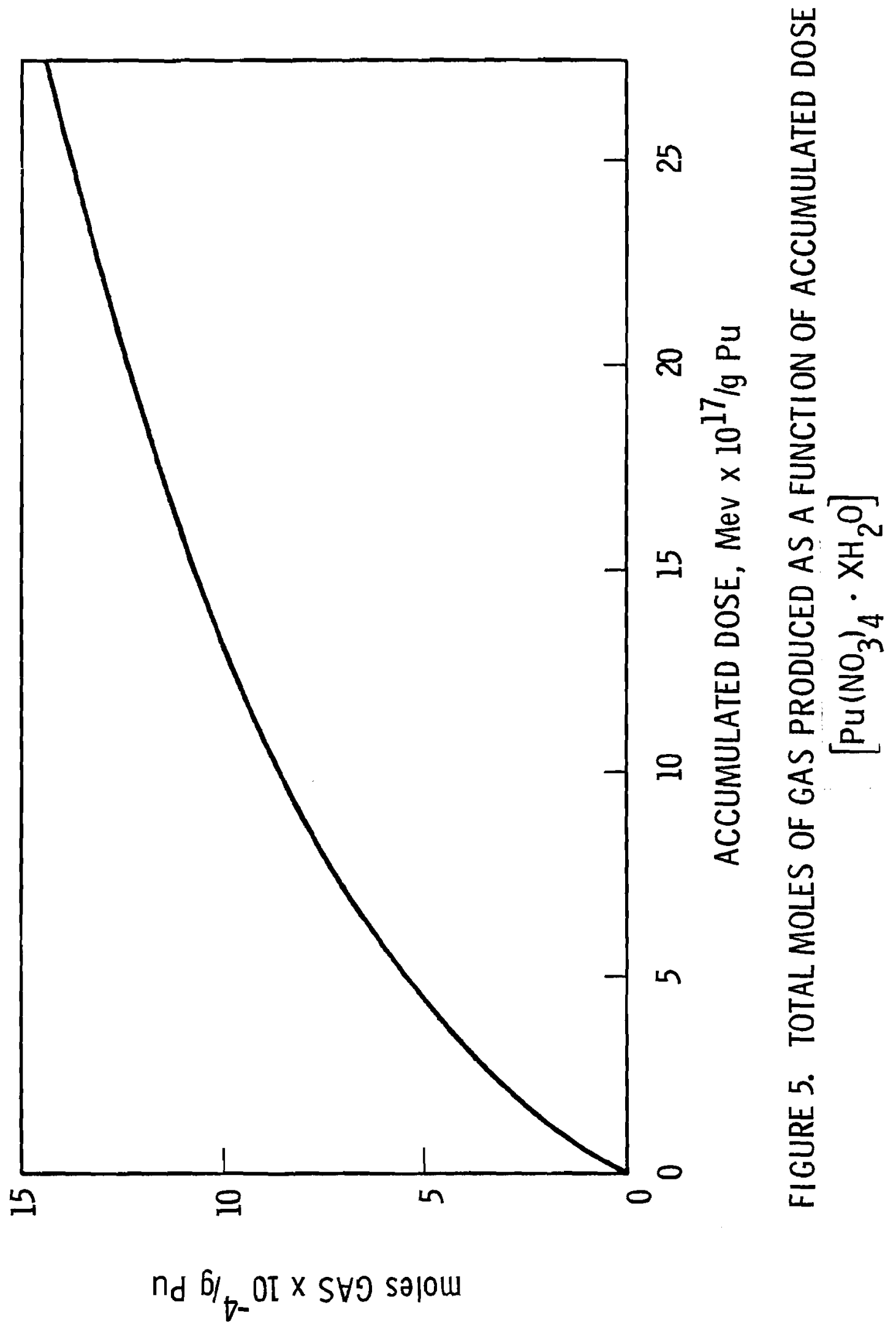




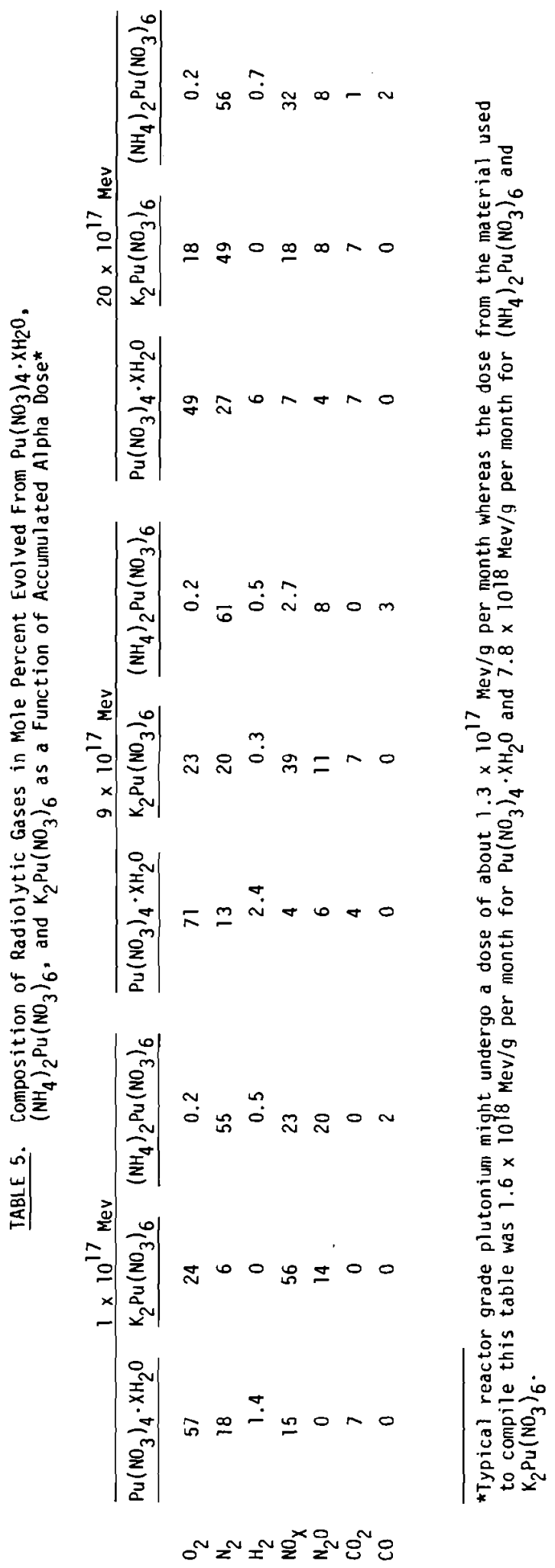


The inorganic nitrates appear to decompose when subjected to ionizing radiation in the following manner:

$$
\mathrm{MNO}_{3} \longrightarrow \mathrm{MNO}_{2}+1 / 2 \mathrm{O}_{2} \text {. }
$$

The variation in yield found when using different cations has been attributed to field strength exerted by the cation on the nitrate ion. (9) Henning, Lees, and Matheson $(10)$ found large differences in yields during radiation decomposition of $\mathrm{NaNO}_{3}$ and $\mathrm{KNO}_{3}$. They felt bonding energy differences were insufficient to account for these differences and proposed that the variation in "free space" might be a possible explanation. "Free space" was defined as the average volume per ion pair minus the average volume of cation and anion as calculated from standard ionic radii. Cunningham and Heal ${ }^{(5)}$ made an extensive study of the radiolysis of several nitrates and their yields (G-values) plotted as a smooth function of free space.

The salts with the smallest free space also had the largest temperature coefficient which supported the free space thesis. The order of decreasing $G$ values was as follows:

$$
\mathrm{KNO}_{3}>\mathrm{CsNO}_{3}>\mathrm{RbNO}_{3}>\mathrm{NaNO}_{3}>\mathrm{LiNO}_{3}
$$

There is an anomoly in this work; however, inasmuch as $\mathrm{CsNO}_{3}$ has subsequently been found to have a higher G-value than $\mathrm{KNO}_{3}$ but a smaller free space. ${ }^{(6)}$

An ambient temperature study of inorganic nitrate decomposition by Chen and Johnson ${ }^{(7)}$ has led to a proposed mechanism that would seem to agree with experimental data. It is as follows:

$$
\begin{aligned}
& \mathrm{NO}_{3}{ }^{-} \longrightarrow \mathrm{NO}_{2}^{-}+0 \\
& 0+\mathrm{NO}_{3}^{-} \longrightarrow \mathrm{NO}_{2}^{-}+\mathrm{O}_{2} \\
& 0+\mathrm{NO}_{2}-\longrightarrow \mathrm{NO}_{3}
\end{aligned}
$$

The back reaction was found to occur in a 11 the nitrates studied and decompositions appeared to approach a steady state. The first derivative of the $\mathrm{NO}_{2}^{-}$yield vs. dose curve ( $\mathrm{dx} / \mathrm{dT}$ where $\mathrm{x}=\mathrm{NO}_{2}{ }^{-}$concentration and $\mathrm{T}$ is proportional to dose) or slope indicates $\mathrm{CsNO}_{3}$ approaches a steady state more rapidly than does $\mathrm{KNO}_{3}$ or $\mathrm{NaNO}_{3}$. This information indicates that the back 
reaction for $\mathrm{CsNO}_{3}$ is much greater than it is for $\mathrm{KNO}_{3}$ which is a more loosely packed lattice or $\mathrm{NaNO}_{3}$ which is a more tightly packed lattice. Free space, therefore, would appear to have no substantial effect on the kinetics of the reaction.

Logan and Moore ${ }^{(11)}$ have indicated that $G$ values are affected by the relative ease of transferring energy to lattice vibrational modes and the density of vibrational states, as well as their average energies. The amount of electronic coupling to lattice vibrations will have some relationship to the polarizability of the cation and to the free space in the lattice and these parameters are also responsible for a particular crystal structure.

Factors such as reactions between radiation induced reaction products, lattice damage from the radiation, stability of primary products and impurities may also be expected to play some role - major or minor - in the radiation decomposition of any given inorganic nitrate. Variations on any or all of these factors may change the yields ( $G$ values) to an appreciable extent.

The ammonium salt is somewhat different inasmuch as the cation itself may be decomposed and is sensitive to the effects of heat and radiation. The radiolytic decomposition at high dose rates of ammonium nitrate has been reported to be comparable to thermal decomposition. Ammonium nitrate volatilizes reversibly at moderate temperatures; irreversibly at higher temperatures giving mainty $\mathrm{N}_{2} \mathrm{O}$ and at still higher temperatures the $\mathrm{N}_{2} \mathrm{O}$ decomposes into nitrogen and oxygen. (1)

Very little oxygen was found in the gaseous products of $\left(\mathrm{NH}_{4}\right)_{2} \mathrm{Pu}\left(\mathrm{NO}_{3}\right)_{6}$; however, a large amount of nitrogen was noted. The low oxygen, high nitrogen and relatively high $\mathrm{NO}_{X}$ content of the gas along with the relatively high $G$ values for this salt indicates a low radiation stability for the ammonium ion. The hydrogen atoms from the ammonium ion presumably end up as water with the nitrate ions furnishing necessary oxygen. Although the total gas evolution from $\mathrm{Pu}\left(\mathrm{NO}_{3}\right)_{4} \cdot \mathrm{XH}_{2} \mathrm{O}$ and $\mathrm{K}_{2} \mathrm{Pu}\left(\mathrm{NO}_{3}\right)_{6}$ are similar, the former produces a larger amount of oxygen and a smaller amount of nitrogen oxides than the latter. This variation can probably be attributed to lattice vibrations, cation polarizability, and the other effects discussed previously. Radiolytic 
release of $\mathrm{H}_{2}$ from the water of hydration of $\mathrm{Pu}\left(\mathrm{NO}_{3}\right)_{4} \cdot \mathrm{XH}_{2} \mathrm{O}$ apparently does not become significant until high accumulated radiation dose. To make a measurement of the contribution of any one factor would be extremely difficult and probably cannot be done except on a theoretical basis.

\section{B. Thermal Stability}

Each of the compounds under study; $\left[\mathrm{Pu}\left(\mathrm{NO}_{3}\right)_{4} \cdot \mathrm{XH}_{2} \mathrm{O}, \mathrm{K}_{2} \mathrm{Pu}\left(\mathrm{NO}_{3}\right)_{6}\right.$, and $\left.\left(\mathrm{NH}_{4}\right)_{2} \mathrm{Pu}\left(\mathrm{NO}_{3}\right)_{6}\right]$; was subjected to thermogravimetric analysis. This procedure was carried out in order to determine intermediates that may have formed and to convert the compounds to oxide for molecular weight determinations. A11 runs were made in air to duplicate actual conditions the compounds might be subjected to as a shipping form.

TGA curves for each compound are shown in Figures 6,7 , and 8 . The compound used in each case was freshly made using ${ }^{239} \mathrm{Pu}$ so as to preclude excessive radiation damage. The curve found for $\mathrm{Pu}\left(\mathrm{NO}_{3}\right)_{4} \cdot 3 \mathrm{H}_{2} \mathrm{O}$ (Figure 6) is much the same as that determined by Drummond and Welch ${ }^{(13)}$ for $\mathrm{Pu}\left(\mathrm{NO}_{3}\right)_{4} \cdot 5 \mathrm{H}_{2} \mathrm{O}$. From molecular weight calculations the intermediate has been postulated to be $\mathrm{PuO}_{2}\left(\mathrm{NO}_{3}\right)_{2}$. Spectrophotometric analysis on freshly dissolved solid also indicated the presence of $\mathrm{PuO}_{2}^{+2}$; however, the intermediate formed was not identified by $x$-ray analys is due to its instability.

The simple plutonium nitrate salt suffers from the standpoint of the low temperature required for decomposition. Present shipping cask designs may not be adequate to ship large quantities without thermal degradation from self-heating.

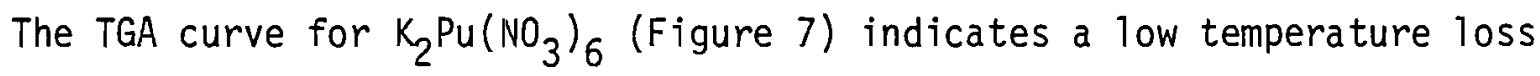
of water. Because of the low temperature at which the water is lost, the water may not be a part of the crystal structure, but rather may be sorbed. This compound also produces a somewhat unstable intermediate, probably of the formula $\mathrm{K}_{2} \mathrm{PuO}_{2}\left(\mathrm{NO}_{3}\right)_{4}$, before decomposition to $\mathrm{KNO}_{3}$ and $\mathrm{PuO}_{2}$. The end point of this TGA is not specific; however, due to slow formation of $\mathrm{K}_{2} \mathrm{O}$ and evaporation of $\mathrm{KNO}_{3}$. The intermediate formed is stable enough to allow the obtaining of an $\mathrm{x}$-ray powder pattern and is apparently not a mixture of $\mathrm{KNO}_{3}$ and $\mathrm{KPu}\left(\mathrm{NO}_{3}\right)_{3}$ as will be described in greater detail under the $x$-ray analys is section. 


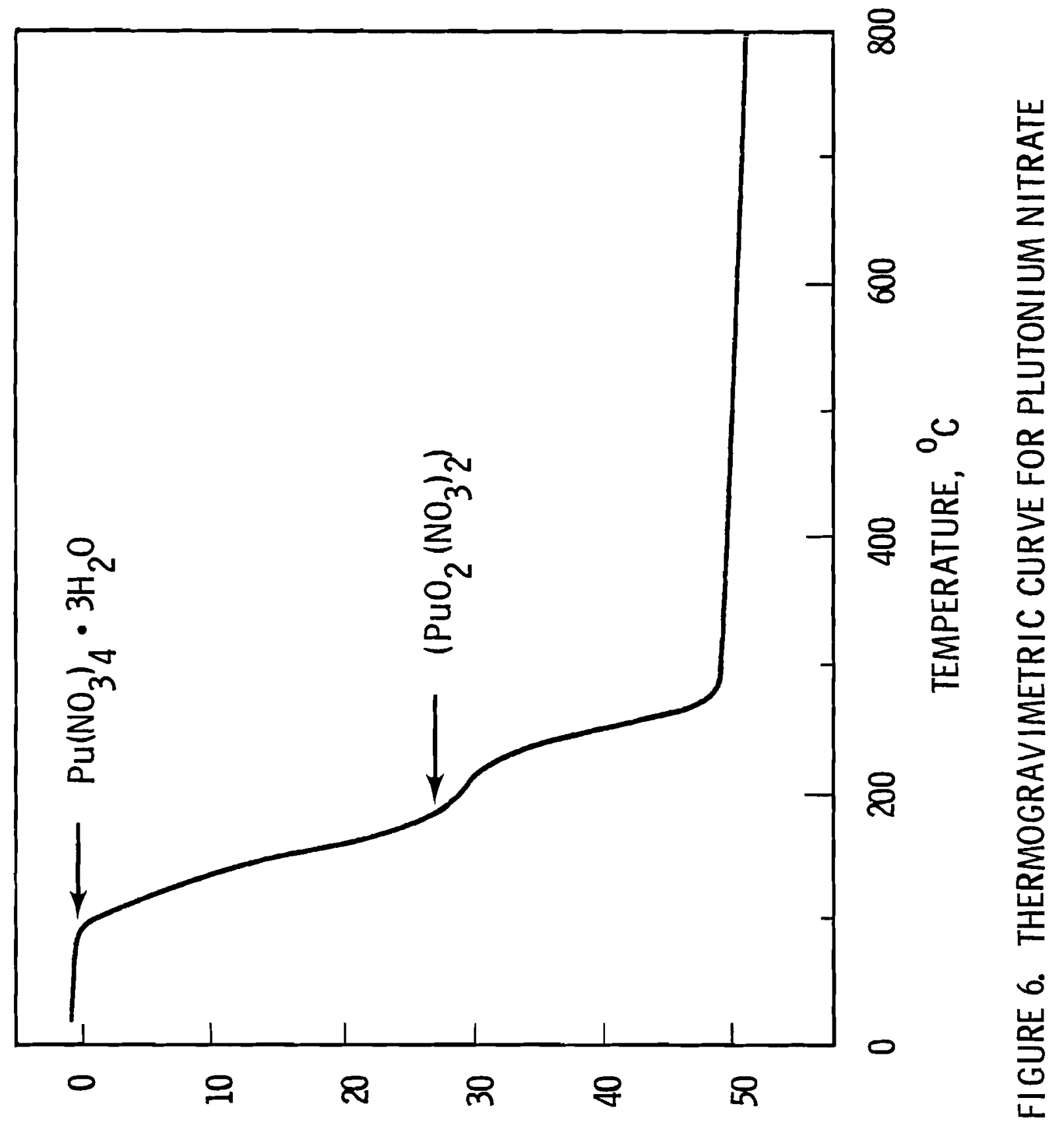

INJJYJd 'SSOT LHOIJM 


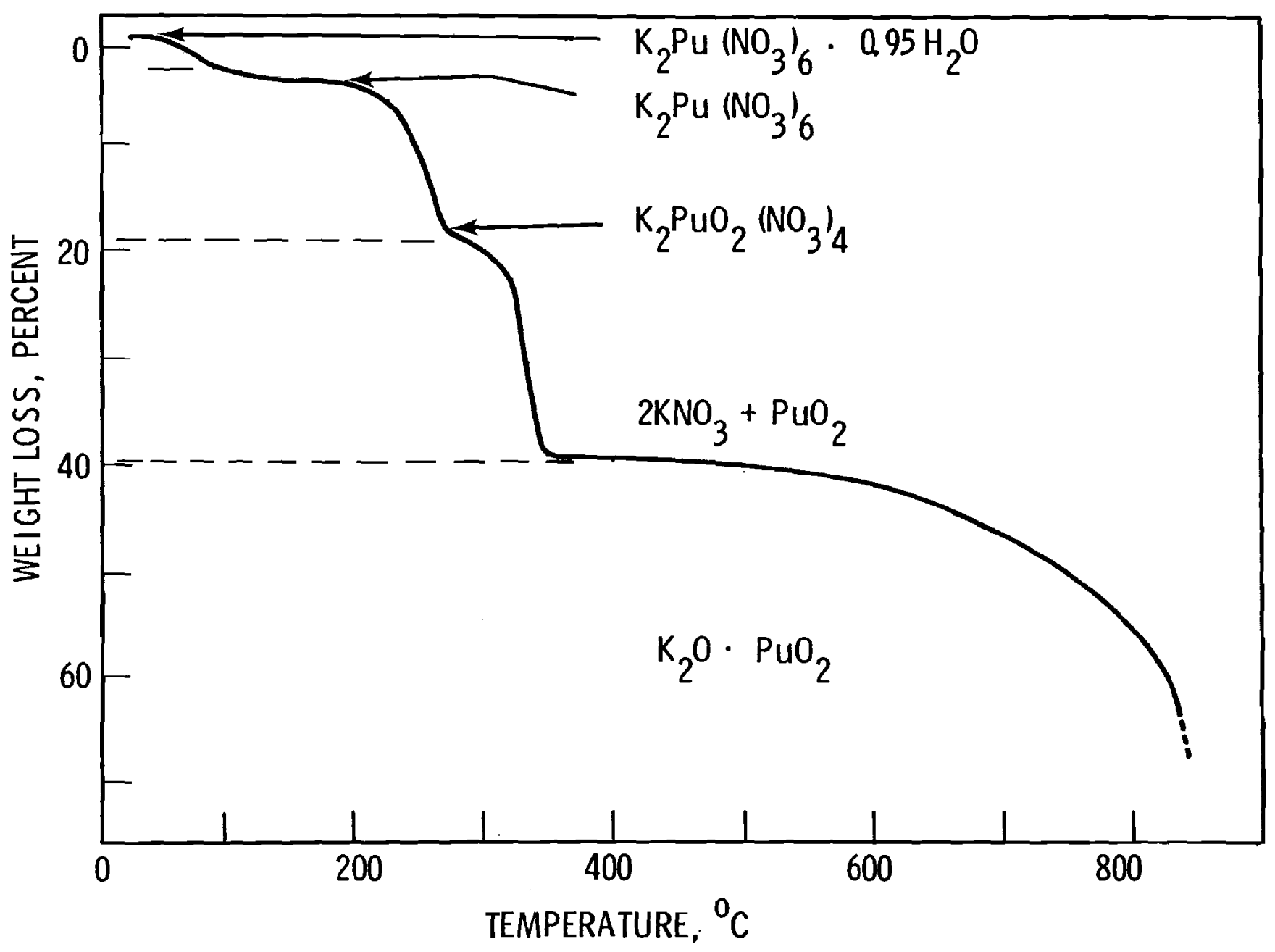

FIGURE 7. THERMOGRAVIMETRIC CURVE FOR POTASSIUM HEXANITRATOPLUTONATE 


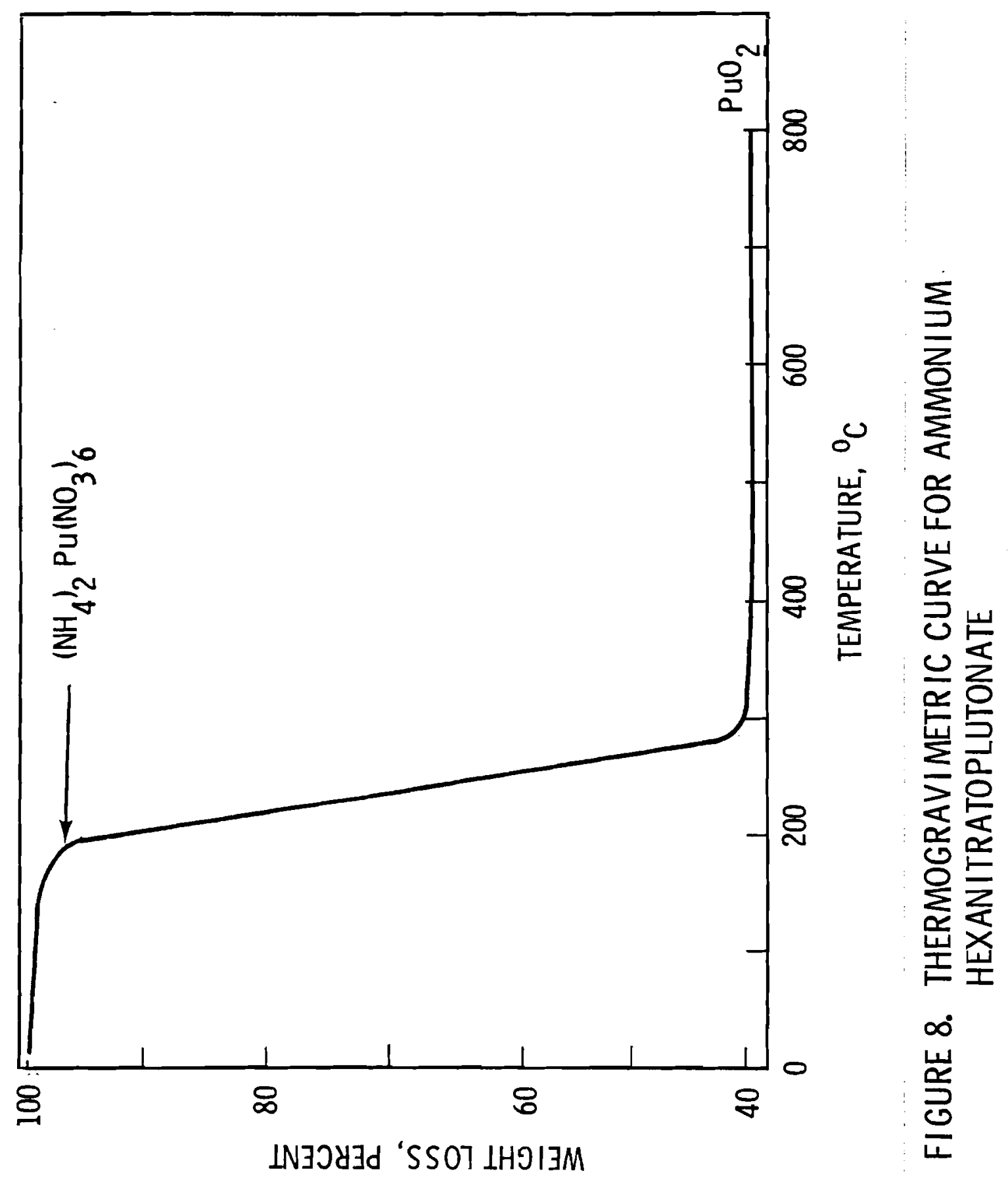


Thermogravimetric analys is of the ammonium salt $\left[\left(\mathrm{NH}_{4}\right)_{2} \mathrm{Pu}\left(\mathrm{NO}_{3}\right)_{6}\right]$ indicated no intermediates were formed (see Figure 8 ). Copious amounts of gas were evolved during the course of the analyses.

C. X-ray Analys is

A11 x-ray patterns of ${ }^{238} \mathrm{Pu}$ salts indicated they were amphorous; presumably from radiolytic breakdown of the crystal structure. Therefore, each of the three salts under study was made from ${ }^{239} \mathrm{Pu}$ to obtain patterns for identification and classification (see Figure 9 ). The intermediate in the thermal degradation of $\mathrm{Pu}\left(\mathrm{NO}_{3}\right)_{4} \cdot \mathrm{XH}_{2} \mathrm{O}$ (as indicated by $\mathrm{TGA}$ ) is unstable and powder pattern identification was not achievable; however, the intermediate found with $\mathrm{K}_{2} \mathrm{Pu}\left(\mathrm{NO}_{3}\right)_{6}$ is sufficientiy stable to produce an $\mathrm{x}$-ray pattern as indicated in Figure 9.

Positive identification of the intermediate formed by heating of $\mathrm{K}_{2} \mathrm{Pu}\left(\mathrm{NO}_{3}\right)_{6}$ has not been achieved. TGA indicates it may be $\mathrm{K}_{2} \mathrm{PuO}_{2}\left(\mathrm{NO}_{3}\right)_{4}$ by molecular weight considerations. X-ray patterns of the intermediate and the well known uranium salt $\left[\mathrm{KUO}_{2}\left(\mathrm{NO}_{3}\right)_{3}\right]$ do not compare indicating that it is probably not a mixture of $\mathrm{KPuO}_{2}\left(\mathrm{NO}_{3}\right)_{3}$ and $\mathrm{KNO}_{3}$. The uranium double salt, $\left[\mathrm{KNO}_{3} \cdot \mathrm{KUO}_{2}\left(\mathrm{NO}_{3}\right)_{3}\right]$, is known, $(14)^{3}$ and it seems likely that the intermediate observed here is similar.

The $x$-ray powder pattern (see Figure 9) obtained for $\mathrm{Pu}\left(\mathrm{NO}_{3}\right)_{4} \cdot 3 \mathrm{H}_{2} \mathrm{O}$ is not the same as that found by Staritzky(15) for $\mathrm{Pu}\left(\mathrm{NO}_{3}\right)_{4} \cdot 5 \mathrm{H}_{2} \mathrm{O}$. The pentahydrate was found to be orthorhombic and isomorphous with the corresponding nitrates of thorium and cerium. It also has 8 formula units per cel1, has a density of 2.90 grams per $c c$, and is hygroscopic.

No known $x$-ray powder patterns are available for $\left(\mathrm{NH}_{4}\right)_{2} \mathrm{Pu}\left(\mathrm{NO}_{3}\right)_{6}$ and $\mathrm{K}_{2} \mathrm{Pu}\left(\mathrm{NO}_{3}\right)_{6}$. Complete analyses of the $x$-ray patterns in each case was not possible; however, further investigation could conceivably give added insight as to the difference in radiolytic decomposition behavior.

D. Effect of Radiation on Solubility

The solubility of each of the three compounds prepared was determined using $84.8 \%{ }^{238} \mathrm{Pu}$ to accelerate experimental test results. The compound $\mathrm{Pu}\left(\mathrm{NO}_{3}\right)_{4} \cdot \mathrm{XH}_{2} \mathrm{O}$ was stored in a dessicator for 171 days and still found to 


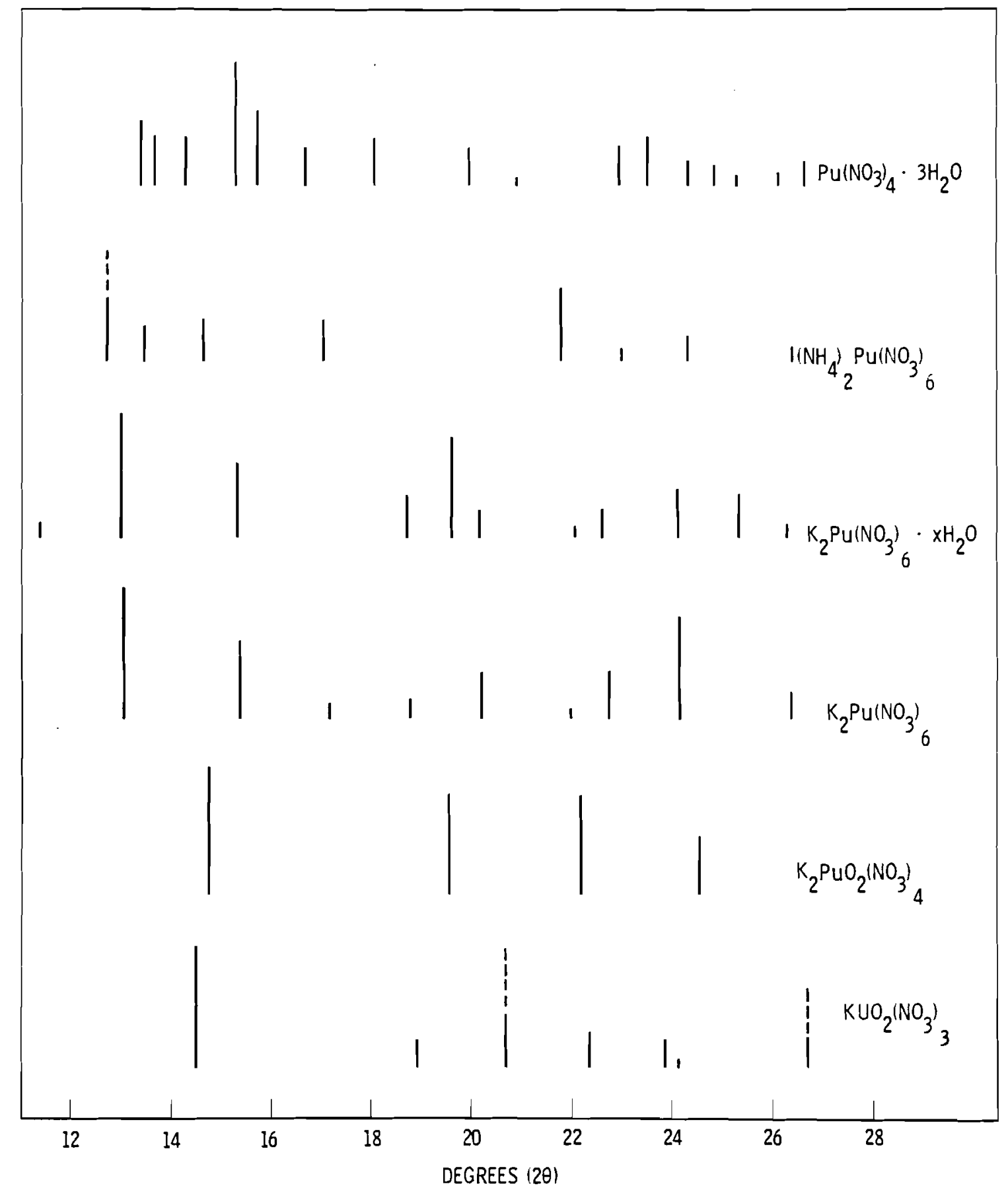

FIGURE 9. X-RAY POWDER DIFFRACTION PATTERNS 
be soluble in $4 \mathrm{M} \mathrm{HNO}_{3}$ at $28^{\circ}$ with 4 hours of agitation. This is equivalent to 25 or more years of radiation damage from reactor grade plutonium. The compound $\mathrm{K}_{2} \mathrm{Pu}\left(\mathrm{NO}_{3}\right)_{6}$ was stored for the reactor grade plutonium radiation equivalent of about five years and $\left(\mathrm{NH}_{4}\right)_{2} \mathrm{Pu}\left(\mathrm{NO}_{3}\right)_{6}$ for the equivalent of about three years, and both were rapidly soluble in $4 \mathrm{MNO}_{3}$ at $25^{\circ} \mathrm{C}$.

Each of the compounds under study was also prepared from ${ }^{239} \mathrm{Pu}$ and stored in a dessicator. The samples were all found to be completely and readily soluble in $4 \mathrm{M} \mathrm{HNO}_{3}$ at $25^{\circ} \mathrm{C}$ after 1.5 years of storage. No further solubility tests were carried out on these compounds; however, complete solubility for several years would be expected.

E. Pilot-Plant Work

The first large-scale production of $\mathrm{Pu}\left(\mathrm{NO}_{3}\right)_{4} \cdot \mathrm{XH}_{2} \mathrm{O}$ was made using 920 grams of plutonium. The resultant solid was a large, dark-green mass that was taken as a single piece from the evaporation vessel. The solid was noted to be hygroscopic when left for extended periods of time exposed to glove box atmosphere.

The evaporation of the plutonium nitrate solution to one liter was accomplished at 180 torr during the first run. The final evaporation to dryness with use of a vacuum pump varied from 9 torr to 2 torr. Several days were required to complete the evaporation as the process was not continuous, and a few minor modifications to the equipment were required. The solution was never a 11 lowed to exceed $80^{\circ} \mathrm{C}$ during the final stages of the evaporation to insure the $\mathrm{Pu}\left(\mathrm{NO}_{3}\right)_{4} \cdot \mathrm{XH}_{2} \mathrm{O}$ was not converted to an insoluble form. Some foaming was noted during the evaporation as the solution became more viscous.

Analytical results of the first run plutonium nitrate solid indicated an excessive amount of water, probably due to insufficient evaporation time. A portion of this material was then dried for 48 hours at 1 torr and ambient temperature. The material was then found to contain $41 \%$ plutonium by weight as determined by chemical analysis. Calcination to an oxide determined its molecular weight to be about $577 \mathrm{gm} / \mathrm{mole}$ indicating 6 waters of hydration. 
The solid was found to be completely soluble in $4 \mathrm{M} \mathrm{HNO}_{3}$. It was also found to be soluble in water but rapidly converted to plutonium polymer.

It is concluded that the plutonium compound $\left(\mathrm{Pu}\left(\mathrm{NO}_{3}\right)_{4} \cdot \mathrm{XH}_{2} \mathrm{O}\right)$ selected also has several other advantages that have not been enumerated in this report. It requires less equipment to prepare than does $\mathrm{PuO}_{2}$, making the overall preparative procedure quite simple. The oxide may also be easily made from the nitrate if desired. The preparation of mixed oxides could be readily achieved by a precipitation step to insure uniform mixing rather than by mechanical mixing of the oxides. Also, as plutonium nitrate is a nitric acid soluble compound, purification just prior to formation of the oxide is easily accomplished if, for example, long storage times before use of the plutonium were necessary and undesirable amounts of americium from ${ }^{241} \mathrm{Pu}$ decay were present.

A possible problem that could arise due to the variable weight of plutonium nitrate could be in plutonium accountability. However, if the plutonium content of the solution prior to evaporation to the solid is known, the amount to be shipped is known. The receiver may then easily check the plutonium content by conversion of a weighed amount to the oxide or by dissolution of the solid in nitric acid for analysis.

Further development of solid plutonium nitrate $\left(\mathrm{Pu}\left(\mathrm{NO}_{3}\right)_{4} \cdot \mathrm{XH}_{2} \mathrm{O}\right)$ would seem desirable in order to allow some flexibility in the shipment of plutonium. Plutonium nitrate may well be the solid form that could supply that flexibility.

BASIS FOR FUTURE SHIPPING PACKAGE DESIGN

Information on several key parameters needed for the design of a shipping package for solid plutonium nitrate is summarized in this section. The purpose of this summary is to provide insight and a starting point for this future development work. Most of the information is based on the chemistry development work described in the previous section. The criticality safety and shielding information was calculated. The studies indicate that no major problems should arise in shipping package development for solid plutonium nitrate. 


\section{Fuel Composition}

A "best estimate" composition of 1st, 2 nd, and 3 rd generation recycle plutonium is given in Table 6 . These compositions are recommended as the basis for neutron and ganma shielding and thermal assessments.

TABLE 6. Estimated Composition of Recycle Plutonium (a)

\begin{tabular}{|c|c|c|c|}
\hline \multirow[b]{2}{*}{ Isotope } & \multicolumn{3}{|c|}{ Isotopic Composition, wt\% } \\
\hline & $\begin{array}{l}\text { 1st } \\
\text { Generation }\end{array}$ & $\begin{array}{l}\text { 2nd } \\
\text { Generation }\end{array}$ & $\begin{array}{c}\text { 3rd } \\
\text { Generation }\end{array}$ \\
\hline${ }^{238} \mathrm{Pu}$ & 1 & 2 & 4 \\
\hline${ }^{239} \mathrm{Pu}$ & 70 & 56 & 47 \\
\hline${ }^{240} \mathrm{Pu}$ & 17 & 24 & 28 \\
\hline${ }^{241} \mathrm{Pu}$ & 10 & 13 & 13 \\
\hline${ }^{242} \mathrm{pu}$ & 2 & 5 & 8 \\
\hline
\end{tabular}

\section{Thermal Decay Energy}

Heat generation within the solid $\mathrm{Pu}\left(\mathrm{NO}_{3}\right)_{4}$ will depend primarily on the ${ }^{238} \mathrm{Pu}$ content and somewhat less on the balance between ${ }^{241} \mathrm{Pu}$ and ${ }^{241} \mathrm{Am}$. The sensitivity of thermal output for recycle plutonium can be estimated from Table 7 . These estimates are based on the physical decay heat constants surmarized in Table 8.

TABLE 7. Estimated Decay Heat For Various ${ }^{241} \mathrm{Pu} /{ }^{241}$ Am Ratios (238pu Held Constant)

Generation

1

2

3

\begin{tabular}{ccc}
\multicolumn{2}{c}{ Decay Heat (watts $/ \mathrm{kg}$ fuel) } \\
$\frac{\mathrm{No}^{241} \mathrm{Am}}{\text { Ratio }}=\infty$ & $\frac{24 \mathrm{Pu}^{241} \mathrm{Am}}{\text { Ratio }}=1$ & $\frac{\mathrm{No}^{241} \mathrm{Pu}}{\text { Ratio }=0}$ \\
8.5 & 12.4 & 18.8 \\
14.6 & 21.2 & 27.9 \\
26.1 & 32.8 & 39.4
\end{tabular}

a. Information provided by E. T. Merri11 (5/75) 
TABLE 8. Thermal Decay Heat Constants For ${ }^{241} \mathrm{Am}$ and Isotopes of Plutonium

\begin{tabular}{|c|c|c|c|c|}
\hline Isotope & $\begin{array}{l}\text { Decay } \\
\text { Mode }\end{array}$ & $\begin{array}{l}\text { Specific } \\
\text { Activity* } \\
\text { (ci/g) }\end{array}$ & $\begin{array}{c}\text { Decay Energy } \\
(\mathrm{MeV})\end{array}$ & $\begin{array}{l}\text { Decay } \\
\text { Heat** } \\
(\mathrm{w} / \mathrm{g}) \\
\end{array}$ \\
\hline${ }^{238} \mathrm{Pu}$ & $\alpha$ & $1.75+1$ & $5.499(72 \%), 5.456(28 \%)$ & $5.70 \times 10^{-1}$ \\
\hline${ }^{239} \mathrm{Pu}$ & $\alpha$ & $6.14-2$ & $5.156(73 \%), 5.143(15 \%), 5.105(12 \%)$ & $1.88 \times 10^{-3}$ \\
\hline${ }^{240} \mathrm{Pu}$ & $\alpha$ & $2.27-1$ & $5.168(76 \%), 5.123(24 \%)$ & $6.96 \times 10^{-3}$ \\
\hline${ }^{241} \mathrm{Pu}$ & $\beta$ & $1.13+2$ & $0.005(0.021 \operatorname{Max})$. & $3.35 \times 10^{-3}$ \\
\hline${ }^{242} \mathrm{Pu}$ & $\alpha$ & $3.9-3$ & $4.903(76 \%), 4.863(24 \%)$ & $1.1 \times 10^{-4}$ \\
\hline${ }^{241} \mathrm{Am}$ & $\alpha$ & $3.24+0$ & $5.486(86 \%), 5.443(13 \%)$ & $1.06 \times 10^{-1}$ \\
\hline
\end{tabular}

** Heat $(w / g)=\operatorname{SpA}(\mathrm{Ci} / \mathrm{g}) * \bar{E}(\mathrm{MeV} / \mathrm{d}) * \frac{3.7 * 10^{10} \mathrm{~d} / \mathrm{sec}}{\mathrm{Ci}} * \frac{1 \mathrm{~W}}{6.243+12 \mathrm{MeV} / \mathrm{sec}}$

Radiolytic Gas Evolution

The composition of radiolytic gases tabulated as function of accumulated $\alpha$-dose are given in Table 5 . These compositions correspond to about 1 month, 7 month, and 15 month doses respectively for typical reactor grade plutonium. In addition, gas evolution data ( $G_{T}$ values) are shown in Figure 4 as a function of accumulated $\alpha$-dose up to $40 \times 10^{17} \mathrm{MeV} / \mathrm{g}$ Pu which would correspond to $21 / 2$ years of storage for reactor grade plutonium. Based on these experimental data, a preliminary appraisal of flammability and pressurization considerations are given below.

Flammability. The lower limit for $\mathrm{H}_{2}$-air mixtures being an explosive hazard is approximately $4 \mathrm{~mole} \% \mathrm{H}_{2}$ in air. The hydrogen evolution for the first two accumulated doses $\left(1 \times 10^{17} \mathrm{MeV} / \mathrm{g} \mathrm{Pu}\right.$ and $\left.9 \times 10^{17} \mathrm{MeV} / \mathrm{g} \mathrm{Pu}\right)$ is below 2.5 mole $\% \mathrm{H}_{2}$, so the evolved gases should pose no problem as an explosive hazard. The hydrogen evolution for an accumulated dose of $20 \times 10^{17} \mathrm{MeV} / \mathrm{g} \mathrm{Pu}$ 
(corresponding to $\sim 15$ months storage for reactor grade plutonium) is 6 mole\% $\mathrm{H}_{2}$ which could pose an explosive hazard if only the radiolytic gas were present. However, one must realize that the radiolytic gases are but a fraction of the total gas accumulated above the material assuming a reasonabie void space in the container. As long as the mixture is less than $2 / 3$ radiolytic gases, the $\mathrm{H}_{2}$ concentration will be below the explosive limit threshold. If one is indeed concerned about flammability for long storage times, the material could be "aged" in a circulating atmosphere before closing the container. Consequently, it is felt that for reasonable storage times $(<3$ years) there should be no explosive hazard due to the $\mathrm{H}_{2}$ gas generation. This should be particularly true if the radiolytic gases are 1) contained within a pressure vessel closed in air under ambient conditions; 2) vented to the atmosphere $\left(\mathrm{H}_{2}\right.$ will preferentially escape); or 3$)$ contained in a pressure vessel which has been flushed with $\mathrm{N}_{2}$ or a noble gas, since in each case the mole\% of $\mathrm{H}_{2}$ will be even lower than in just the radiolytic gases.

Pressurization. Pressurization of the container is a possible problem due to radiolytic gas evolution and material decomposition at elevated temperatures. The pressurization due to radiolytic gas evolution depends upon the integrated $G_{T}$ curve (see figure 5 ) and the void volume of the container. Assuming temperatures below the threshold for material decomposition

$$
P(t)=\frac{P_{0}^{T}(t)}{T_{0}} \times\left(1+\frac{R T_{0}}{V} \int_{0}^{t} G_{T}(\tau) d \tau\right)
$$

where $P(t), T(t)$ are the pressure and temperature at time $t$;

$P_{0}, T_{0}$ are the pressure and temperature at the time of sealing;

$V$ is the void volume of the container;

$R$ is the gas constant; and

$G_{T}(t)$ is the radiolytic gas evolution rate as a function of time.

At el evated temperatures two possible modes of decomposition of $\mathrm{Pu}\left(\mathrm{NO}_{3}\right)_{4}$. $\mathrm{XH}_{2} \mathrm{O}$ are obvious:

$$
\mathrm{Pu}\left(\mathrm{NO}_{3}\right)_{4} \cdot \mathrm{XH}_{2} \mathrm{O}+\Delta \longrightarrow \mathrm{PuO}_{2}\left(\mathrm{NO}_{3}\right)_{2}+2 \mathrm{NO}_{2}+\mathrm{XH}_{2} \mathrm{O}\left(\frac{2+X \text { moles gas }}{\text { mole compound }}\right)
$$




$$
\mathrm{Pu}\left(\mathrm{NO}_{3}\right)_{4} \cdot \mathrm{XH}_{2} \mathrm{O}+\underset{\left(\sim 300^{\circ} \mathrm{C}\right)}{\longrightarrow} \mathrm{PuO}_{2}+\mathrm{O}_{2}+4 \mathrm{NO}_{2}+\mathrm{XH}_{2} \mathrm{O} \quad\left(\frac{5+X \text { moles gas }}{\text { mole compound }}\right)
$$

It is quite apparent that pressurization must be seriously considered as a safety problem under such adverse conditions.

Shielding. Dose rates were calculated for $2 \mathrm{~kg}, 10 \mathrm{~kg}$, and $25 \mathrm{~kg} \mathrm{Pu}$ as $\mathrm{Pu}\left(\mathrm{NO}_{3}\right)_{4} \cdot 2 \mathrm{H}_{2} \mathrm{O}$ with a density of $2.0 \mathrm{~g} / \mathrm{cm}^{3}$ in spherical geometry with $1 / 4$ " stainless steel cladding assuming 1 year since separation. Results are presented in Table 9 for shielding calculations. The dihydrate form is considered to be conservative relative to the pentahydrate form.

TABLE 9. Estimated Dose Rates For Recycle Plutonium

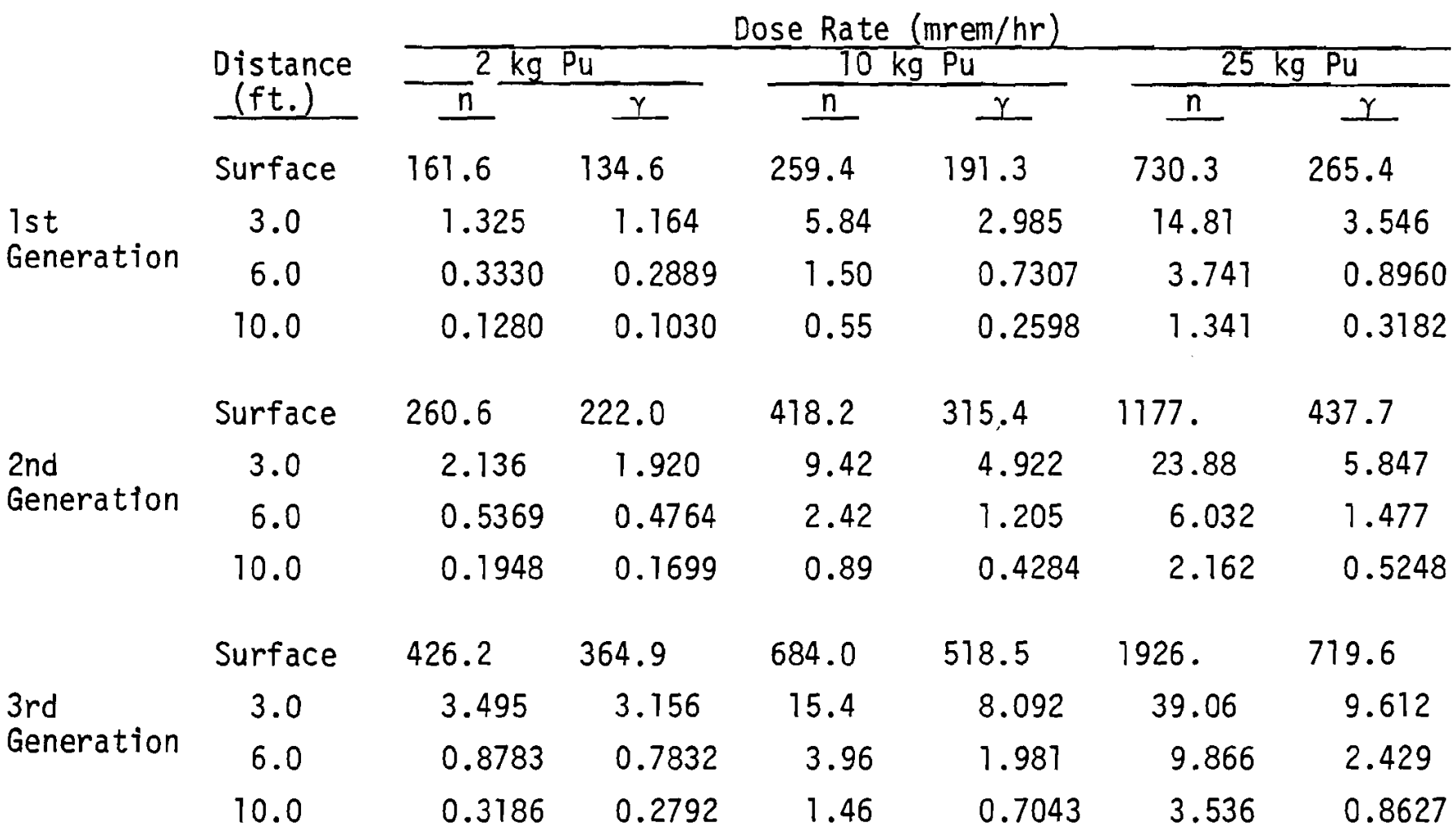


Criticality. Criticality parameters for $\mathrm{Pu}(80 / 10 / 10)$ as both $\mathrm{Pu}\left(\mathrm{NO}_{3}\right)_{4}$. $5 \mathrm{H}_{2} \mathrm{O}$ and $\mathrm{PuO}_{2}$ were calculated for Pu densities from $10 \mathrm{~g} / \ell$ up to theoretical density. GAMTEC II cross-sections in the one-dimensional diffusion theory code HFN were used for the highly moderated systems and Hansen-Roach crosssections in the Monte Carlo code KENO III were used for the undermoderated and dry systems. The density - $\mathrm{H} / \mathrm{Pu}$ atom ratio relationship used in the calculations is given in Figure 10. Results are presented in Tables 10, 11, and 12. Note that the pentahydrate form is considered to be a worse case than the dihydrate form for criticality investigation.

TABLE 10. $\mathrm{Pu}\left(\mathrm{NO}_{3}\right)_{4} \cdot 5 \mathrm{H}_{2} \mathrm{O}-$ Spherical Geometry

\begin{tabular}{|c|c|c|c|c|c|c|}
\hline Concentration & \multicolumn{3}{|c|}{ Bare } & \multirow{2}{*}{\multicolumn{3}{|c|}{ Reflected }} \\
\hline$P(g \mathrm{Pu} / \mathrm{l})$ & $\underline{R_{c}(\mathrm{~cm})}$ & Volume $(\ell)$ & $\underline{M_{c}(\mathrm{~kg} P u)}$ & $\underline{R_{C}(\mathrm{~cm})}$ & Volume $(\ell)$ & \\
\hline 1201 & 20.8 & 37.7 & 45.3 & 16.0 & 17.2 & 20.6 \\
\hline 1000 & 20.7 & 37.2 & 37.2 & 15.9 & 16.8 & 16.8 \\
\hline 300 & 19.2 & 29.6 & 8.89 & 14.65 & 13.2 & 3.95 \\
\hline 100 & 18.4 & 26.1 & 2.61 & 14.8 & 13.6 & 1.36 \\
\hline 70 & 18.6 & 27.0 & 1.89 & 75.1 & 14.4 & 1.01 \\
\hline 50 & 19.2 & 29.6 & 1.48 & 15.8 & 16.5 & 0.826 \\
\hline 30 & 21.3 & 40.5 & 1.21 & 18.0 & 24.4 & 0.733 \\
\hline 20 & 24.9 & 64.7 & 1.29 & 21.7 & 42.8 & 0.856 \\
\hline 10 & 53.0 & 624. & 6.24 & 49.8 & 517. & 5.17 \\
\hline
\end{tabular}




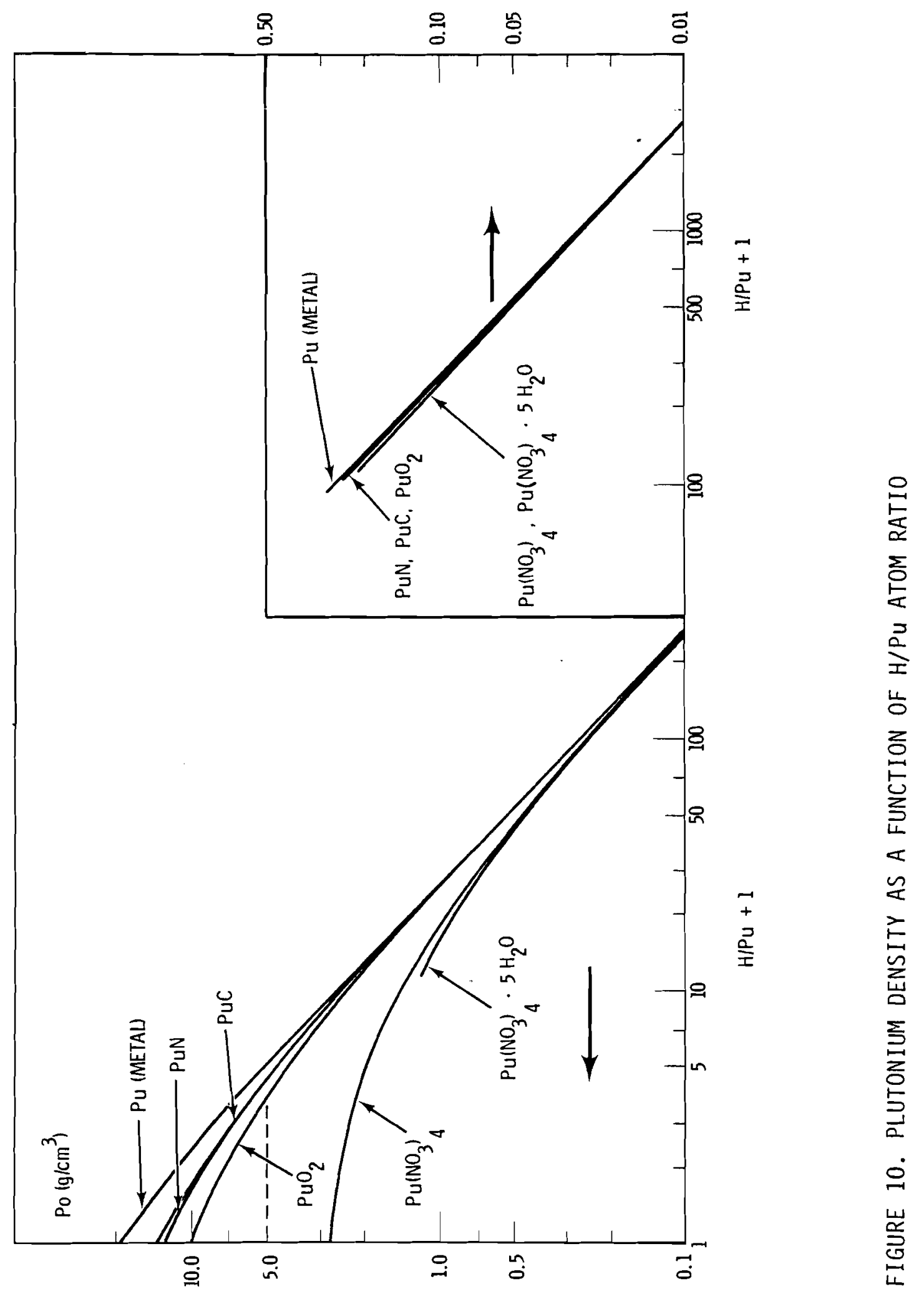


TABLE 11. $\mathrm{PuO}_{2}$ - Spherical Geometry

Concentration $\mathrm{p}(\mathrm{g} \mathrm{Pu} / \mathrm{Q})$

10107
3000
1000
300
100
70
50
30
20
10

Bare $\underline{R_{c}(\mathrm{~cm}) \text { Volume(2) } M_{c}(\mathrm{~kg} P u)}$

$$
8.3
$$$$
2.40
$$$$
13.5
$$

17.2

10.3

21.3

17.7

23.2

17.9

24.0

18.2

25.3

18.9

28.3

21.1

39.3

24.7

63.1

52.2596.
24.2

30.9

21.3

6.97

2.40

1.77

1.41

1.18

1.26

5.96

\begin{tabular}{|c|c|c|}
\hline \multicolumn{3}{|c|}{ Reflected } \\
\hline$R_{c}(\mathrm{~cm})$ & Volume (2) & $M_{c}(\mathrm{~kg} P u)$ \\
\hline 6.61 & 1.21 & 12.2 \\
\hline 10.4 & 4.71 & 14.1 \\
\hline 13.0 & 9.20 & 9.20 \\
\hline 13.8 & 11.0 & 3.30 \\
\hline 14.4 & 12.5 & 1.25 \\
\hline 14.8 & 13.6 & 0.951 \\
\hline 15.6 & 15.9 & 0.795 \\
\hline 17.8 & 23.6 & 0.709 \\
\hline 21.5 & 41.6 & 0.832 \\
\hline 49.0 & 493. & 4.93 \\
\hline
\end{tabular}

TABLE 12. Cylindrical Geometry - Critical Radius (cm)

\begin{tabular}{|c|c|c|c|c|}
\hline & \multicolumn{2}{|c|}{$\mathrm{Pu}\left(\mathrm{NO}_{3}\right)_{4} \cdot 5 \mathrm{H}_{2} \mathrm{O}$} & \multicolumn{2}{|c|}{$\mathrm{PuO}_{2}$} \\
\hline $\mathrm{p}\left(\mathrm{g}^{\prime} \mathrm{Pu} / \mathrm{l}\right)$ & Bare & Reflected & Bare & Reflected \\
\hline 10107 & - & - & 6.0 & 3.95 \\
\hline 3000 & - & - & 10.0 & 6.45 \\
\hline 1201 & 15.4 & 10.8 & - & - \\
\hline 1000 & 15.5 & 10.9 & 12.5 & 8.45 \\
\hline 300 & 14.0 & 9.8 & 13.0 & 9.1 \\
\hline 100 & 13.6 & 9.8 & 13.2 & 9.5 \\
\hline 70 & 13.7 & 10.1 & 13.4 & 9.8 \\
\hline 50 & 14.2 & 10.6 & 14.0 & 10.5 \\
\hline 30 & 15.8 & 12.4 & 15.6 & 12.3 \\
\hline 20 & 18.6 & 15.3 & 18.4 & 15.1 \\
\hline 10 & 40.0 & 36.7 & 39.4 & 36.1 \\
\hline
\end{tabular}




\section{REFERENCES}

1. Zs. Szentirmay and J. Patko, Z. Physik. Chem., Neve Folge, Bd 83, S. 13 (1973)

2. J. C. Sheppard, USAEC Report, BNWL-751, May 1968.

3. N. E. Bibler, J. Phys. Chem., 78, 211 (1974).

4. C. J. Hochanadel and T. W. Davis, J. Phys. Chem. 27, 333 (1957).

5. J. Cunningham and H. G. Heal, Trans. Faraday Soc., 54, 1355 (1958).

6. E. R. Johnson, J. Am. Chem. Soc., 80, 4460 (1958).

7. T. Chen and E. R. Johnson, J. Phys. Chem., 66, 2249 (1962).

8. J. Cunningham, J. Phys. Chem., 65, 628 (1961).

9. P. Doigan and T. W. Davis, J. Phys. Chem., 57, 764 (1952).

10. G. Henning, R. Lees, and M. Matheson, J. Chem. Phys., 21, 664 (1953).

11. S. R. Logan and W. J. Moore, J. Phys. Chem., 67, 1042 (1963).

12. F. A. Cotten and G. Wilkinson, Advanced Inorganic Chemistry, 3rd ed. Interscience Publishers, New York, 1972.

13. J. L. Drummond and G. A. We1ch., J. Chem. Soc., 2565 (1956).

14. A. A. Lipovskii, and M. G. Kuzima, Radiokhimiya, 5, 268 (1963).

15. E. Staritzky, Anal. Chem., 28, 2021 (1956). 


\section{APPENDIX 1}

Amendment to 10 CFR Part 71 ,

"Packaging and Transportation of Radioactive Material"

20.623-2 Regulations-Nuclear Regulatory Commission 52 3-28-75

$[\pi \quad 14,833 j]$

tSec. 71.41. Previously constructed packages for irradiated solid nuclear fuel.--Notwithstanding any other provisions of this Subpart, a package, the use of which has been authorized by the Commission for the transport of irradiated solid nuclear fuel on or after September 23, 1961, and which has been completely constructed prior to January 1, 1967, shall be deemed to comply with the package standards of this subpart for that purpose.

$$
\text { [ } \left.\begin{array}{ll}
\pi & 14,833 \mathrm{k}
\end{array}\right]
$$

Sec. 71.42. Special requirements for plutonium shipments after June $17, \cdot 1978 . .-$ (a) Notwithstanding the exemption in 71.9 , plutonium in excess of twenty (20) curies per package shall be shipped as a solid.

(b) Plutonium in excess of twenty (20) curies per package shal1 be packaged in a separate inner container placed within outer packaging that meets the requirements of Subpart $C$ for packaging of material in normal form. The separate inner container shall not release plutonium when the entire package is subjected to the normal and accident test conditions specified in Appendices A and B. Solid plutonium in the following forms is exempt from the requirements of this paragraph.

(1) Reactor fuel elements;

(2) Metal or metal alioy; or

(3) Other plutonium bearing solids that the Commission determines should be exempt from the requirements of this section.

(c) Authority in licenses issued pursuant to this part for delivery of plutonium to a carrier for transport under conditions which do not meet the limitations of paragraphs (a) and (b) of this section shall expire on June 17, 1978.

[Sec. 71.42 as added June 17, 1974, effective Ju1y 17, 1974 (39 F. R. 20960); amended effective March 3, 1975 (40 F. R. 8792).] 
No. of

Copies

OFFSITE

3

2

1

1

1

2
All ied-General Nuclear Services P.0. Box 847

Barnwe11, South Carolina 29812

Ralph E. Best

John H. Gray

A. K. Williams

Battelle Memorial Institute

Columbus Laboratories

505 King Avenue

Columbus, Ohio 43201

David G. Freas

Mike Pobereskin

Combustion Engineering

1000 Prospect Hill Road

Windsor, Connecticut 06095

Rockwel1 International

Atomics International Division

Rocky Flats Plant

P.0. Box 464

Golden, Colorado 80401

D. A. Wiederecht

E. I. duPont delNemours \& Co. Savannah River Plant

Aiken, South Carolina 29801

H. J. Groh, Jr.

Exxon Nuclear Company

Richland, WA 99352

G. L. Ritter

R. K. Robinson

General Electric Company

Nuclear Fuel Department

P.0. Box 780

Castle Hayne Road

Wilmington, N. C. 28401

Carl Cliche

Tom L. Gregory

Arthur L. Kaplan 
General Electric Company

Midwest Fuel Recovery Plant

Morris, Illinois 60450

E. G. Pierick

1

General Electric Company

Reactor Fuels and Reprocessing Dept.

175 Curtner Avenue

San Jose, California 95125

R. G. Barnes

4

General Electric Company

Vallecitos Nuclear Center

P.0. Box 846

Pleasanton, California 94566

E. A. Aitken

E. F. Kurtz

C. Wesley Smith

I. N. Taylor

1

Kerr-McGee Nuclear

$133 \mathrm{~N}$. W. Robert S. Kerr Avenue

Oklahoma City, Oklahoma 73102

W. J. Shelley

1

Nuclear Fuel Services, Inc.

6000 Executive Building

Suite 600

Rockville, Maryland 29852

Richard L. Booth

2

NUMEC

609 North Warren Avenue

Apol10, PA. 15613

Dale Smay

Charles R. Woods

Oak Ridge National Laboratory

Oak Ridge, Tennessee 37830

L. B. Shappert

W. C. Ulrich 
No. of

Copies

OFFSITE

1

Sandia Laboratories

P. 0. Box 5800

Albuquerque, New Mexico 87115

James F. Ney, Organization 1741

1

1

2

1

4

R. M. Horgos

R. E. 01 sen

Westinghouse Electric Corporation

P. 0. Box 2068

Idaho Falls, Idaho 83401

Wayne Stevens

U. S. Energy Research and Development Administration Washington, D. C. 20545

William Brobst, WMT

E. K. Loop, DOS

James A. Sisler, WMT

Norman R. Thielke, SNS

U. S. Energy Research and Development Administration

Chicago Operations office

9800 South Cass Avenue

Argonne, Illinois 60439

Carl G. Ahlberg

A. A. Churm 
OFFSITE

119

U. S. Energy Research and Development Administration Technical Information Center

2

Nuclear Regulatory Commission Washington, D. C. 20545

R. D. Smith

Frank Swanberg

ONSITE

14

Battelle Memorial Institute

Pacific Northwest Laboratories

T. W. Ambrose

C. L. Brown

G. H. Bryan

R. E. Burns

N. E. Carter

J. L. McElroy

R. E. Nightingale

A. M. Platt

J. K. Thompson

L. D. Will iams

H. H. Van Tuyl

Technical Files (2)

Technical Publications

Energy Research and Development Administration Richland Operations Office

P. A. Craig

R. F. Garrison

A. R. Schwarkoff

J. H. Straub

D. J. Squires

2

Energy Research and Development Administration FFTF Program Office

D. E. Crouter

R. L. Ferguson

ARHCO

R. E. Felt

P. C. Ely 
No. of

Copies

ONSITE

HEDL

E. A. Evans

J. J. Keating

R. C. Smith 